\title{
Transformative Technology in Microfinance: Delivering Hope ELECTRONICALLY?
}

\author{
By Shanthi Elizabeth Senthe \\ Volume XIII - Fall 2012
}

\begin{abstract}
Considered a lifeline, and a convenience, a mobile phone has now acquired another transformative dimension within the microfinance context. As a result of the proliferation of mobile banking in emerging markets and developing countries, microfinance institutions ("MFIs") have adopted similar technological enhancements to deliver microfinance products. This paper will explore how emerging technology advances has altered the contours of microfinance, specifically mobile banking (also known as " $m$-banking") which is utilized to facilitate efficient financial services to a vast number of people without access to the formal banking system and financial services, otherwise known as the "unbanked". This discussion offers a snapshot of the current state of mobile banking, and examines the kaleidoscopic approach used by microfinance institutions through several auxiliary considerations. Part I examines the underlying rationale in employing a cashless banking paradigm and illustrates how mobile banking is administered institutionally. Part II seeks to highlight the regulatory considerations intractable within the mobile banking discourse, and is intended to provide a survey of the current regulatory landscape, and finally, Part III focuses on uncovering the consumer perspective, and calls for a conceptual refinement in the interconnection of the social context within mobile banking.

This paper is not intended to be categorized as a comparative law piece; rather its primary objective is to provide a snapshot of how certain jurisdictions have embraced mobile banking platforms and their legislative response thereto. This discussion is merely offered as part of a functionalist approach discourse currently adopted by regulators; as such this paper only offers a cursory perspective of emerging legal considerations within the mobile banking context as it relates to MFIs.
\end{abstract}




\title{
Transformative Technology in Microfinance: Delivering Hope ELECTRONICALLY?
}

\author{
By Shanthi Elizabeth Senthe* \\ Volume XIII - Fall 2012
}

\section{Table of Contents}

PART 1: INSTITUTIONAL STRUCTURING ................................................................ 5

A. The Acute Need for Mobile Banking.............................................................................. 5

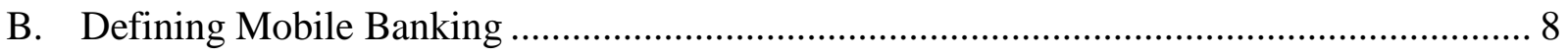

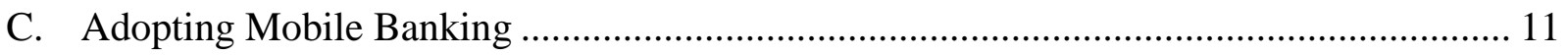

1. Modes of Business Organization.......................................................................... 12

2. Telco-Led Model............................................................................................ 15

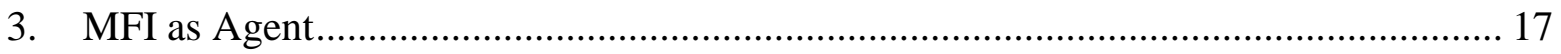

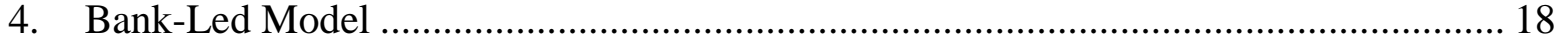

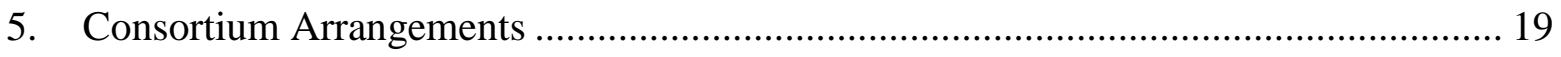

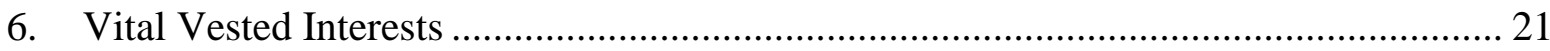

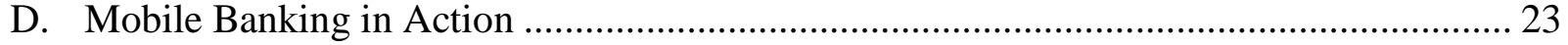

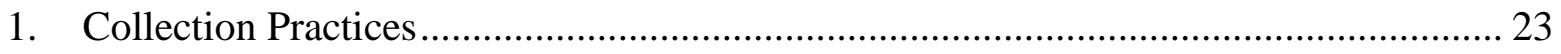

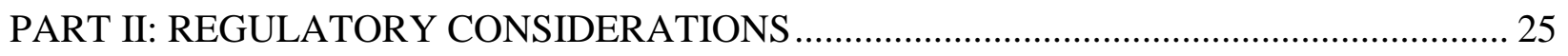

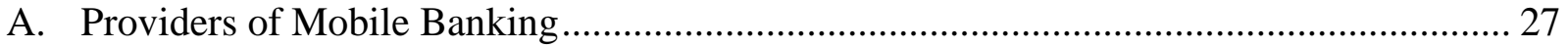

B. Be An Agent or Use An Agent? ............................................................................ 29

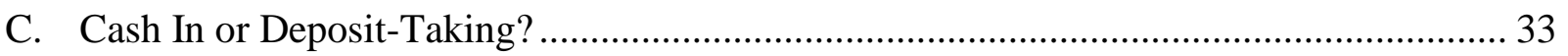

D. Who Can Issue E-Money during M-Banking? ............................................................ 34

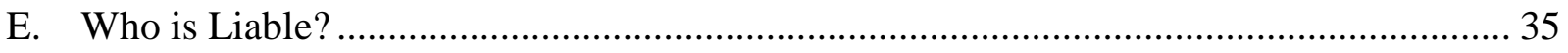

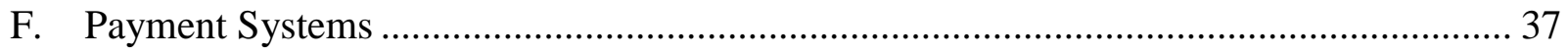

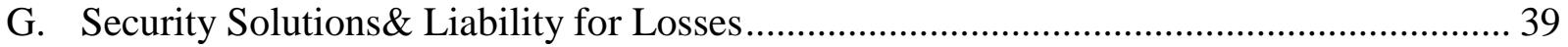

\footnotetext{
* Shanthi Elizabeth Senthe, J.D. (Florida State University College of Law), LL.M, Ph.D. Candidate (Osgoode Hall Law School), Senior Fellow, Critical Research Laboratory in Law \& Society, Osgoode Hall Law School, York University. The author wishes to thank Professor Benjamin Geva for his encouragement and guidance. In particular, the author is also grateful for edits and comments provided by Christian Chamorro-Courtland, Ruby Dhand and Sujith Xavier.
} 
H. Liability for Losses .................................................................................. 43

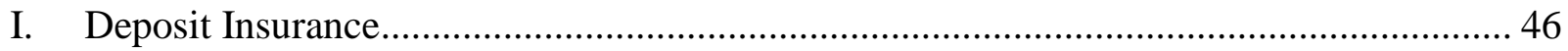

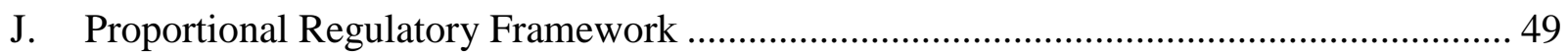

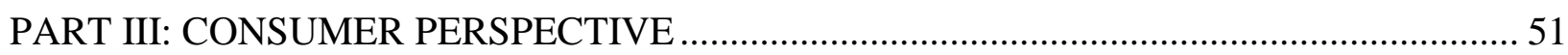

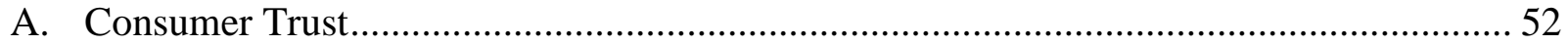

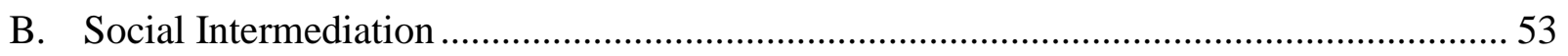

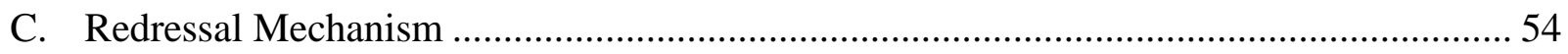

D. Gender Empowerment through Digital Activism ...................................................... 56

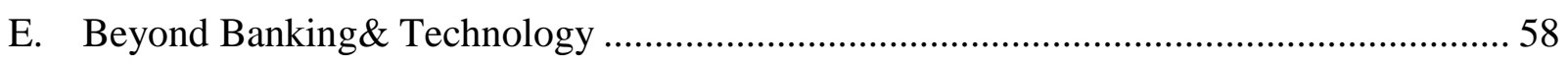

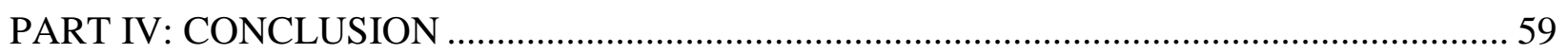




\section{INTRODUCTION}

Already considered a lifeline, and a convenience, the mobile phone has now acquired another transformative dimension within the microfinance context ${ }^{1}$. Due to the proliferation of mobile banking in emerging markets and developing countries, microfinance institutions ("MFIs") ${ }^{2}$ have adopted similar technological enhancements to deliver microfinance products, such as microcredit, microsavings, microinsurance, and remittance services, to promulgate financial inclusion and access. It is estimated that roughly 2.7 billion people lack basic formal financial services, including savings accounts. ${ }^{3}$ Microfinance has been perceived as a pseudo modern day panacea for global poverty, as it promises a glimmer of economic hope by directly providing financial services to those systematically excluded due to poverty, lack of collateral, and lack of creditworthiness.

This paper will explore how emerging technology advances have altered the contours of microfinance. In particular, it will focus on how mobile banking (also known as "m-banking") is utilized to facilitate efficient financial services to a vast number of people who lack access to the formal banking system and financial services, otherwise known as the "unbanked." These "unbanked" individuals can be distinguished from those who are "underbanked." Unlike "unbanked" individuals, the "underbanked" individuals only have "nominal access" to poor

\footnotetext{
${ }^{1}$ Microfinance is described as a provision of small scale financial services to individuals who lack access to banks and other formalized financial entities.

${ }^{2}$ Gautam Ivatury, Using Technology to Build inclusive Financial Systems, in NEW PARTNERSHIPS FOR INNOVATION IN MicrofinANCE 147 (I. Matthaus-Maier \& J. D von Pischke eds., 2d ed. 2009) (referring to microfinance institutions as "nongovernmental organizations (NGOs), cooperatives, banks, and licensed nonbank institutions that focus on delivering financial services to microentrepreneurs and other low-income clients, generally using new lending techniques that have been developed during the past 30 years.").

${ }^{3}$ IFC, Microsave report Supports Increase in Microsavings for India's Low-Income Clients, THE PAK BANKER (Mar. 17, 2011), available at http://www.ifc.org/IFCExt/pressroom/IFCPressRoom.nsf/0/72C00AC8CC799C0885257854004A58EA?OpenDocu ment.
} 
quality financial services. ${ }^{4}$ This discussion offers a snapshot of the current state of mobile banking, and examines the kaleidoscopic approach used by microfinance institutions through several auxiliary considerations. Part I examines the underlying rationale in employing a cashless banking paradigm and illustrates how mobile banking is administered institutionally. Part II seeks to highlight the regulatory considerations intractable within the mobile banking discourse, and is intended to provide a survey of the current regulatory landscape. Finally, Part III focuses on uncovering the consumer perspective, and calls for a conceptual refinement in the interconnection of the social context within mobile banking.

This paper is not intended to be categorized as a comparative law piece; rather, its primary objective is to provide a snapshot of how certain jurisdictions have embraced mobile banking platforms and their legislative response thereto. ${ }^{5}$ In order to pursue a deep comparative study of the underlying regulatory measures employed by the numerous jurisdictions discussed below, a full historical, post-colonial and legal theoretical inquiry is required. However, this discussion is merely offered as part of a functionalist approach discourse currently adopted by regulators. Consequently, this paper only offers a cursory perspective of emerging legal considerations within the mobile banking context as it relates to MFIs.

The frenetic evolution of mobile banking in developing countries has attracted a growing interest due to the rapid financial impact derived from these seemingly tiny wireless handheld devices. The success of mobile banking can be attributed to its ubiquity, reliability and real time phenomenon. ${ }^{6}$ However, regulatory issues have emerged as more and more jurisdictions employ

\footnotetext{
${ }^{4}$ Claudia McKay and Mark Pickens, Branchless Banking 2010: Who's Served? What Price? What's Next?, 66 CGAP FOCUS NOTE 4 (2010), available at http://www.cgap.org/publications/branchless-banking-2010who\%E2\%80\%99s-served-what-price-what\%E2\%80\%99s-next.

${ }^{5}$ In this paper, I attempted to use local informants to provide the current mobile banking narrative. I cited and relied on local media sources and opinion pieces written by local reporters and insiders when available.

${ }^{6}$ Jongho Kim, Ubiquitous Money and Walking Banks: Environment, Technology, and Competition in Mobile Banking, 8 RiCH. J. GLOBAL L. \& BuS. 37 (2009).
} 
mobile banking as part of their banking practices. Regulatory issues are a large component in the mobile banking context, ${ }^{7}$ and this has been especially true for microfinance institutions (MFIs).

\section{Part I: Institutional Structuring}

\section{A. The Acute Need for Mobile Banking}

The necessity for mobile banking in developing countries is predicated on economic, geographic, cultural, and social elements. As segments of the global population continue to live in severe poverty, fragmented attempts have been offered to provide viable economic solutions. Within this context, microfinance was conceived as a tool to alleviate poverty and to create selfempowerment through financial access. In particular, microcredit is "offered for creating selfemployment for income generating activities and for housing for the poor, as opposed to consumption."8 It is essential to recognize that consumers of microfinance cannot be characterized as a homogenous populace. They are culturally, socially and economically dissimilar, and are also not equally skilled to become micro-entrepreneurs. Many live within a purely cash-based economy, frequently participating in sachet-based purchasing whereby consumers can only afford to buy small amounts at a time. ${ }^{9}$ The utility of cash is often based on consumer control, security and necessity, which are manifested in various forms.

\footnotetext{
${ }^{7}$ Michael Klein \& Colin Mayer, Mobile Banking and Financial Inclusion: The Regulatory Lessons, in THE WORLD BANK, at 4, available at http://wwwwds.worldbank.org/servlet/WDSContentServer/WDSP/IB/2011/05/18/000158349_20110518143113/Re ndered/PDF/WPS5664.pdf (last visited July 27, 2012) (to date, 50 mobile banking platforms have been deployed world-wide).

${ }^{8}$ Aneel Karnani, Microfinance Needs Regulation, in STANFORD SOCIAL INNOVATION REVIEW, at 48 (2011), available at http://www.ssireview.org/articles/entry/microfinance_needs_regulation/ (quoting the Grameen website).

9 "Sachet Purchasing is the practice of purchasing goods in very small quantities. This phenomenon is known to be common in other developing markets where the populace rely on cash for all trading and can afford to buy provisions for just a few days' consumption. This market does not exhibit bulk purchase tendencies and an mCommerce offering that involves a significant cash deposit or payment will be unlikely to find any significant
} 
Under this rubric, MFIs are charged with providing small-sum, high-volume transactions to the unbanked. Delivering financial services to indigent individuals is an expensive endeavor as MFIs use varying methodologies to calculate risks in issuing loans and services without credit histories or collateral, often in the absence of technological infrastructure. To combat administrative and operational costs, many MFIs charge interest on microloans and services in order to remain financially sustainable. ${ }^{10}$ By implementing a mobile banking platform, many of these MFIs are able to defray overhead costs. At the local level, operation costs are reduced as manual collection and cash handling are no longer necessary. ${ }^{11}$ To illustrate, within the microcredit process, a loan officer designated to a specific geographic area convenes weekly meetings, and collects the repayment installments. The loan officer typically has multiple meetings per day and is in physical possession of cash as during travel from village to village. ${ }^{12}$ In some countries, MFIs hire security personnel to accompany the loan officer for safety reasons. With the implementation of mobile banking, "the loan disbursement and collection process is enhanced by removing cash handling and security risks."13 Mobile banking provides for condensed weekly meetings, and it allows consumers to partially pay their loans whenever their businesses realize a profit. ${ }^{14}$ Furthermore, onerous business practices, such as manual recordkeeping, data collection, and documentation gathering, can be relinquished. This process also provides heightened anonymity, and preserves privacy for microfinance recipients.

uptake from the target market." Micro-Payment Systems and Their Application to Mobile Networks, MICROFINANCE GATEWAY (Jan. 2006), available at

http://www.microfinancegateway.org/gm/document-1.9.28276/36206_file_M_commerce_infoDev.pdf.

${ }^{10}$ This has remains to be a contentious debate within microfinance industry as the underlying premise of charging interest to the most vulnerable consumers runs counter to the poverty reduction agenda. However, as significant as this issue is, it is beyond the scope of this paper.

${ }^{11}$ As narrated in the SMART initiative in the Philippines. Video Blog: What Are The Various Roles That MFIs Can Play In Mobile Money? Microfinance: From Manual to Mobile Enabled, available at http://www.gsma.com/mobilefordevelopment/programmes/mobile-money-for-the-unbanked/products/mmuproducts-credit/.

${ }^{12} I d$.

${ }^{13} I d$.

${ }^{14} I d$. 
From a consumer perspective, mobile banking can be life changing by creating more autonomy, gender empowerment, and in some cases, overcoming illiteracy. These aspects of mobile banking are further discussed in Part III of this paper. A simple hand-held device can offer security and storage capability, thus removing the need to store physical cash under the mattress or conceal it on the person. Mobile banking "absorbs the cash that had previously been performing the store-of-value function (under the mattress)" and provides a cash conversion functionality, thereby moving towards a cashless society. ${ }^{15}$ Not only are physical security risks averted through mobile banking, but the reach of branchless banking is limitless and facilitates immediate financial access. Residents within rural communities, which are often spatially excluded from financial institutions, resort to creating their own currency storage mechanisms. Some residents store cash in pots, later discovering that the currency is of no value due to depreciation or that it has been physically destroyed by vermin, such as rats or insects (red ants). ${ }^{16}$

A rural community located in the Amazon in Brazil faced hardship in accessing financial services; consumers had to embark on a twelve-hour journey by boat to reach the nearest banking facility, or pay $\$ 5-\$ 10$ for a designated individual to make the trip on their behalf. ${ }^{17}$ Mobile banking successfully plugs these communities into immediate financial services through inexpensive technology, thereby creating new capital flows. This in itself is revolutionary as it "releases money flow in countries that have poor infrastructure and often are in crisis

\footnotetext{
${ }^{15}$ Ingacio Mas \& Kabir Kumar, Banking on Mobiles: Why, How and for Whom?, 48 CGAP Focus NOTE 8 (2008),

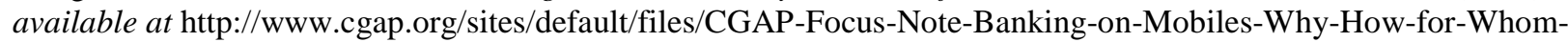
Jul-2008.pdf.

${ }^{16}$ Benjamin Kwasi Addom, Mobile Money Service: An Innovation for Rural Women, INTEGRA (Oct. 14, 2011), http://www.integrallc.com/2011/10/14/mobile-money-service-an-innovation-for-rural-women/.

${ }^{17}$ McKay \& Pickens, supra note 4, at 7.
} 
situations. ${ }^{~} 18$ Branchless banking alleviates the pressures of investing in a physical infrastructure, especially in rural areas. Mobile banking serves as a link between informal financial arrangements to the modern economy. It serves to close the gap, which separated communities from market participation. ${ }^{19}$ The urban epicenter of banking has created the "possibility for banks to maintain a constant presence in their customer's lives. ${ }^{.20}$ The cellphone has transformed from a communication tool or a payment device, into a savings vehicle as well. ${ }^{21}$ As mobile banking has become an indispensable component within the financial infrastructure of many jurisdictions, regulators are struggling to develop appropriate legislation.

\section{B. Defining Mobile Banking}

Defining mobile banking is difficult, especially when multiple stakeholders are involved in the development, implementation and settlement stages. As such, numerous definitions have been offered to classify mobile banking. A few are as follows:

Mobile Banking is defined "as a broad term for the use of a mobile phone to access financial services and trigger a financial event, it does not assume any specific deployment model or any particular transaction type."22

and

Mobile banking allows customers to use their mobile phone as another channel for their banking services, such as deposits, withdrawals, account transfer, bill payment, and balance inquiry. Most mobile banking applications are additive in that they provide a

\footnotetext{
${ }^{18}$ Kevin Voigt, Mobile Phone: Weapon Against Global Poverty, CNN (Oct. 2011), http://articles.cnn.com/2011-1009/tech/tech_mobile_mobile-phone-poverty_1_mobile-phone-cell-phone-rural-villages?_s=PM:TECH (quoting Olga Morwcyznksi).

${ }^{19}$ It is significant to note at this juncture, that informal participation in the market simply describes activities and transactions that are outside the regulatory framework. Further, this paper does not advocate that inclusive formal market participation is a desired goal. Rather, this discussion will center on the current policy agenda.

${ }^{20}$ Ignacio Mas \& Colin Mayer, Savings as Forward Payments: Innovations on Mobile Money Platforms 5 (Sept. 2, 2011) (unpublished manuscript) (available at http://ssrn.com/abstract=1825122).

${ }^{21} I d$.

${ }^{22}$ Pierre-Laurent Chatain et Al., Protecting Mobile Money Against Financial Crimes: Global Policy Challenges AND Solutions, at xxvii (World Bank Publications, 2011).
} 
new delivery channel to existing bank customers. Transformative models integrate unbanked populations into the formal financial sector. ${ }^{23}$

and

Mobile Banking can be defined as "the use of mobile-phone-based interfaces to provide account information and transaction opportunities to customers of financial institutions." 24

and finally,

Mobile Banking refers to provision and availment of banking and financial services with the help of mobile telecommunication devices. The scope of offered services may include facilities to conduct bank and stock market transactions, to administer accounts and to access customized information. ${ }^{25}$

At first glance, the definitions appear to be conceptually similar. However, closer examination reveals that the first definition can be described as a "catch all" classification. Conversely, the other three definitions are more technical in nature and descriptive of the actual process, but may not capture new technological changes within mobile banking. Consequently, the first definition outlined above may be preferred due to its broad description. The source for the divergent definitions can be attributed to the originators of the terminology, such as development, telecommunications, and finance institutions. Industry insiders have long held that a consensus around the terminology must be established as "it does become critical at the

\footnotetext{
${ }^{23}$ Janine Firpo, E-Money - Mobile Money - Mobile Banking - What's the Difference?, WORLD BANK PRIVATE SECTOR DEV. BLOG (Jan. 21, 2009), http://blogs.worldbank.org/psd/e-money-mobile-money-mobile-banking-whats-the-difference.

${ }^{24}$ Jennifer Tescher et al., Mobile Financial Services and the Underbanked: Opportunities and Challenges for Mbanking and Mpayments, in CENTER FOR FINANCIAL SERVICES INNOVATION, at 6 (Apr. 2007), available at http://cfsinnovation.com/system/files/imported/managed_documents/mbanking.pdf.

${ }^{25}$ Rajnish Tiwari, Stephan Buse \& Cornelius Herstatt, Customer on the Move: Strategic Implications of Mobile Banking for Banks and Financial Enterprises 4 (Hamburg University of Technology Institute of Technology \& Innovation Management, Working Paper No. 38, 2006), available at http://papers.ssrn.com/sol3/papers.cfm?abstract_id=1583825.
} 
regulatory level as well as when potential players are trying to have a meaningful conversation with each other."26

Within this definitional dilemma, jurisdictional issues arise as each jurisdiction establishes its own country-specific definition of mobile banking. For instance, the Reserve Bank of India defines mobile banking as "undertaking banking transactions using mobile phones by bank customers that involve credit and debit to their accounts." 27 This definition also includes non-monetary transactions, such as account balance inquiries and bank communications. Another proposition offered is not to include mobile banking within a definitional framework structured for banking concepts, as mobile payments may not include banking features. $^{28}$

Industry insiders have proposed the term, mobile transactions, in lieu of mobile banking, as the term 'transacting' is generally associated with using the ATM, and 'banking' is used to describe access to the individual's account via the internet, or at a branch. ${ }^{29}$ The distinction is based on the notion that the use of the ATM is a transactional activity, which allows the customer to move funds, whereas at the bank, the customer acquires additional services, such as savings, deposits and loans. ${ }^{30}$ Mobile banking therefore suggests activity that contracts "new

\footnotetext{
${ }^{26}$ Firpo, supra note 23, n.3.

${ }^{27}$ Nikhil Pawa, Chart: Mobile Banking Transactions In India - May 2009 To Feb 2011, MEDIANAMA (Apr. 19, 2011), http://www.medianama.com/2011/04/223-chart-mobile-banking-transactions-in-india/.

${ }^{28} \mathrm{Kim}$, supra note 6, at $42 \mathrm{n} .17$ ("'[s]ince mobile payment constitutes an independent business field that does not necessarily involve banks, some researchers have not considered it as a mobile banking category."); Id. at 43 n. 22 ("[i]n one public report, the term mobile banking is used broadly to refer to the delivery of banking services through mobile phones."); Rajnish Tiwari et al., Mobile Services in Banking Sector: The Role of Innovative Business Solutions in Generating Competitive Advantage 3 (Technische Universitat Hamburg-Harburg, Working Paper No. 48, Feb. 2007) (noting that there are different ways of defining mobile banking: "Mobile Banking refers to provision and availment of banking and financial services with the help of mobile telecommunication devices. The scope of offered services may include facilities to conduct bank and stock market transactions, to administer accounts and to access customized information.").

${ }^{29}$ Claire Alexandre, Ignacio Mas \& Daniel Radcliffe, Regulating New Banking Models to Bring Financial Services to All, Challenge MAGAZINE, May/June 2011, at 116, 119, available at http://ssrn.com/abstract=1664644. ${ }^{30} \mathrm{Id}$.
} 
services over the mobile phone." 31 At this juncture, it is significant to note that the term "mobile banking" should not be confused with "mobile money transfers," which are defined "as the process of two-parties exchanging money using a mobile device, such as mobile phones, wireless devices, computers or PDAs in return for goods and services." 32 This definition clearly is distinguished from mobile banking.

The lack of a widely accepted definition becomes problematic when establishing regulatory measures. Conversely, if mobile banking remains undefined, it may be easier to capture various transactions under the 'mobile banking' framework. In the microfinance context however, a uniform definition of mobile banking must be adopted to ensure consistency due to its cross-border implications with respect to remittance services, and its impact on payment systems.

\section{Adopting Mobile Banking}

The recent success in mobile banking can be attributed to the microfinance movement in its early inception. The Kenyan narrative with M-PESA serves as the origination of mobile banking for the delivery of microfinance. In 2005, M-PESA was designed as a pilot project to facilitate microfinance payments for Faulu, a microfinance institution. ${ }^{33}$ However, due to technical and structural challenges in its early stages, the mobile banking uptake failed. ${ }^{34}$ Safaricom, the mobile network operator, observed customer usage patterns and determined that

${ }^{31} I d$.

${ }^{32}$ Marc Bourreau \& Marianne Verdier, Cooperation for Innovation in Payment Systems: The Case of Mobile Payment 7 n.8 (Telecom ParisTech, Working Paper, 2010), available at http://papers.ssrn.com/sol3/papers.cfm?abstract_id=1575036.

${ }^{33}$ Kabir Kumar, Claudia McKay \& Sarah Rotman, Microfinance and Mobile Banking: The Story So Far, CGAP (2010), at 7, available at http://www.cgap.org/publications/microfinance-and-mobile-banking-story-so-far (noting that Faulu Kenya later transformed into the first deposit taking microfinance institution in Kenya in 2009).

${ }^{34}$ IFC, M-MONEY CHANNEL DISTRIBUTION CASE - KENYA 4 (2010), available at http://www.microfinancegateway.org/p/site/m//template.rc/1.9.50997. 
customers were creatively changing the course of mobile banking. ${ }^{35}$ This user-driven innovation changed the microfinance dynamics by sparking non-attendance of group meetings, thereby creating a "breakdown in repayment discipline."36

Further, this consumer behavior prompted Safaricom to market its product to the public. ${ }^{37}$ Given its history with mobile banking, Faulu's story has come full circle as it recently partnered with Airtel, an Indian telecommunications company to use mobile banking in disbursing loans. ${ }^{38}$ Microfinance recipients can now access loans and repay them via a mobile phone. ${ }^{39}$

\section{Modes of Business Organization}

MFIs have begun to adopt mobile banking as part of their banking platform due to the extensive gains realized. Mobile banking is $19 \%$ cheaper than traditional banking services. ${ }^{40}$ MFIs are no longer required to invest in physical infrastructure, human resources, or transportation costs. ${ }^{41}$ Branchless banking has allowed MFIs to become virtual banks and serve an enormous number of rural residents at a low cost without overhead expenditures. Typically, MFIs incur higher costs in delivering small sum transactions to remote locations. ${ }^{42}$

Without mobile banking, MFIs were compelled to charge high interest to cover registration, transaction and administrative costs. These costs are associated with training employees, risk management initiatives and security for personnel who deliver funds to remote areas. The use of SMS messaging serves as an example of how MFIs have lowered their costs

\footnotetext{
${ }^{35}$ Kumar, McKay \& Rotman, supra note 33, at 7.

${ }^{36} \mathrm{Id}$.

${ }^{37} \mathrm{Id}$.

${ }^{38}$ Brett Cohen, Faulu Kenya Airtell Form Partnership to Offer Mobile Credit, MiCROCAPITAL (May 19, 2012), http://www.microcapital.org/microcapital-brief-faulu-kenya-airtel-form-partnership-to-offer-mobile-credit/.

${ }^{39}$ Id. (stating that consumers can also use Faulu Popote, which is a mobile savings feature and money transfer service).

${ }^{40}$ McKay \& Pickens, supra note 4, at 2.

${ }^{41}$ Mas \& Kumar, supra note 15 , at 1.

${ }^{42}$ Id.
} 
by merely adopting automatic text messaging systems to notify their clients of payment dates, thereby precluding the need to physically call or send reminders. ${ }^{43}$ Studies have demonstrated that mobile banking reduces costs by $50 \%$ in South Asian initiatives. ${ }^{44}$ These cost savings can be attributed to a "very lean branch model." 45

MFIs pursue a number of approaches in developing a mobile banking system. A shared mobile banking venture can be accomplished either by a bank-led model, or MNO-led model, also known as a 'telco-led model.' As these models suggest, the partnership between the MFI and the bank (with the MNO as the delivery agent), or the MFI and the telecommunications company, can facilitate mobile banking platforms.

In establishing these mobile banking platforms, MFIs must balance the various choices of implementation, such as: (1) customer experience and services to be offered, (2) security and privacy considerations, and (3) whether third parties will be participating in the mobile venture. ${ }^{46}$ Studies conducted by the CGAP indicate that MFIs creating an independent mobile banking payment system may not be a viable solution for MFIs unless there is an absence of an existing mobile banking platform. A shared venture between a mobile provider and an MFI is more cost effective. The costs of building infrastructure are often not feasible for individual microfinance institutions. $^{47}$ In order for technology to fully penetrate the microfinance sector, collection of customer information and its administration must be standardized. ${ }^{48}$

\footnotetext{
${ }^{43}$ Kumar, McKay \& Rotman, supra note 33, at 6 (estimating that sending text messages may save MFI loan officers an hour a day).

${ }^{44}$ Arnaud Ventura et al., Beyond Payments: Next Generation: Mobile Banking for the Masses, PlaNet FinANCE 1, 5 (2011), http://admin.planetfinancegroup.org/upload/medias/fr/mobile_money_brochure.pdf.

${ }^{45} I d$. at 6.

${ }^{46}$ Mas \& Kumar, supra note 15, at 11.

${ }^{47}$ Janine Firpo, Banking the Unbanked: Issues in Designing Technology to Deliver Financial Services to the Poor, in NeW PARTNERSHIPS For INNOVATION In MiCROFINANCE 194, 196 (I. Matthaus-Maier \& J. D von Pischke eds., $2 \mathrm{~d}$ ed. 2009), available at http://technology.cgap.org/2010/09/08/virtual-conference-day-1-session-2-should-an-mfiin-a-country-without-any-existing-m-banking-infrastructure-create-its-own-m-banking-system/.

${ }^{48} I d$. at 196.
} 
Development of infrastructure is essential for viable technological innovations; as such, MFIs can embark on a solo venture in investing in an entire mobile microfinance platform. This is a very costly proposition as these MFIs individually absorb all expenses in developing electronic banking and wireless infrastructure.

In Malawi, the Opportunity International Bank of Malawi (“OIBM”) launched mobile banking by building a mobile service from the ground up in May 2010. ${ }^{49}$ The underlying rationale for this business decision rested on the fact that there was an absence of existing mobile service to engage in a shared partnership. ${ }^{50}$ In addition, the OIMB had prior extensive experience with implementing highly advanced banking processes, such as biometric automated teller machines, and mobile vans. ${ }^{51}$ The OIMB had to navigate regulatory and technological channels and upgrade its entire system to create a comprehensive mobile banking system. ${ }^{52}$ In order to extend its reach to rural areas, the OIMB entered into a partnership with an "agricultural supply store.",53

Hence, although the bank developed its own mobile banking initiative, collaborative efforts facilitated the outreach. Furthermore, the mobile banking system was implemented under the auspices of the Reserve Bank of Malawi. ${ }^{54}$ This particular case study demonstrates the level of support MFIs require from regulators to properly implement mobile banking structures.

\footnotetext{
${ }^{49}$ Transcript of Virtual Conference Day 1, Session 2: Should an MFI in a country without any existing m-banking infrastructure create its own m-banking system?, CGAP (Sept. 8, 2010) (transcript on file with author) [hereinafter Transcript Day 1 Session 2].

${ }^{50} I d$.

${ }^{51}$ Kumar, McKay \& Rotman, supra note 33, at 1.

${ }^{52} I d$. at 3 .

${ }^{53} I d$.

${ }^{54}$ Transcript Day 1 Session 2, supra note 49.
} 


\section{Telco-Led Model}

Unlike the OIMB example, most MFIs join forces with existing mobile banking platforms. Prior to launching a mobile banking service, MFIs are heavily reliant on partnerships with mobile network operators ("MNOs"), which are usually telecommunication carriers and technological groups. These MNOs essentially serve as the "backbone" of any mobile banking platform as it provides the communication frequency. ${ }^{55}$ MNOs simply act as messengers of the transaction from provider to consumer, or they provide "mobile wallet services," which encompasses a storage facility of transactions and management of accounts ${ }^{56}$. MNOs also engage in account hosting services by maintaining accounts in financial institutions but management of these are under the purview of the MNO. ${ }^{57}$

Furthermore, MFIs require strong technological, marketing and service relationships to trim the costs associated with establishing the mobile banking system. Therein lies a risk that MFIs will be unable to persuade mobile operators to participate if the mobile operators deem that the operation is not commercially viable. ${ }^{58}$ Achieving strategic alliances is primarily based on a profit-model, as MNOs prefer volume-driven transactions. ${ }^{59}$

Furthermore, MNOs are more inclined to engage in a partnership if MFIs have resorted to sharing existing mobile banking infrastructure for cost-sharing purposes, thereby reducing their costs and providing the mobile operator with additional customers to service. However, recent studies have indicated that merely implementing mobile banking services does not necessarily

\footnotetext{
${ }^{55}$ CHATAIN ET AL., supra note 22, at xiii-xiv.

${ }^{56}$ Ignacio Mas \& Jim Rosenberg, The Role of Mobile Operators in Expanding Access to Finance, CGAP (May 2009), http://www.gsma.com/mobilefordevelopment/wpcontent/uploads/2012/06/br_role_mobile_operators_expanding_access_d_23.pdf.

${ }^{57} I d$.

${ }^{58}$ Mas \& Kumar, supra note 15 , at 18.

${ }^{59}$ Kumar, McKay \& Rotman, supra note 33, at 5 (large scale operations are needed to create a partnership incentive).
} 
guarantee an influx of new mobile subscribers in the microfinance context. ${ }^{60}$ This is partly due to the fact that microfinance services are heavily reliant on face-to-face meetings and "human interactions."61 Therefore, the ongoing challenge for MFIs is to create a synergistic framework, which combines mobile banking services with a personal touch.

In some jurisdictions, the use of 'mobile coaches' (individuals who provide cell phone use training) by MNOs not only creates service and product awareness among communities, but also provides a distinctive and individualized service for mobile banking customers. These mobile coaches are described as "feet on the street partners," who act as conduits between the MNO and the MFI. ${ }^{62}$ These sub-agents manage consumer relationships and assist in training, "customer handholding and usage facilitation."63 This particular business practice illustrates the customized methods used by different telecom providers in facilitating mobile banking transactions for microfinance recipients while concomitantly serving to promote financial inclusion. The cultural ambulation underpinning the uptake of mobile banking is significant and deserves further exploration.

Once mobile operators and MFIs enter into a partnership with a telecommunications entity to develop mobile banking, the deployment model can be tailored to fit the needs of the MFIs. MFIs can purchase simple wireless connectivity from the telecommunications carrier to merely send messages to its customer base or they can apply Subscriber Identity Module ("SIM") services with security and communication capabilities. ${ }^{64}$

\footnotetext{
${ }^{60} \mathrm{Id}$ at 12.

${ }^{61}$ Id. ("Loan Officers are well known in the communities in which they operate, and frequent face-to-face meetings are essential to strengthen the social capital on which the methodology is based.").

${ }^{62}$ Ventura et al., supra note 44, at 5, 24.

${ }^{63} I d$.

${ }^{64}$ Mas \& Kumar, supra note 15 , at 18-19.
} 
Certain MFIs employ mobile operators to administer the communications components, so that "the mobile banking channel looks like a stream of transactions coming down a single pipe. ${ }^{.65}$ Alternatively, mobile operators may manage and administer the entire mobile banking platform, whereby mobile operators become an extension of the MFIs. ${ }^{66}$ As mobile operators in effect become agents of MFIs, regulatory obligations may attach, depending in which jurisdiction the operation is based. ${ }^{67}$

\section{MFI as Agent}

Another proposed business model to further branchless banking is to utilize MFIs as "network managers of agents, ${ }^{, 68}$ or simply put, agents for commercial financial institutions. ${ }^{69}$ Under this partnership structure, banks enlist MFIs to provide financial services to unbanked and rural communities. In Colombia, proponents of this particular model believe it to be a viable option due to its unique legal and financial landscape. Financial institutions in the formal sector have extended mobile banking services for its existing clients. However, specific efforts to use branchless banking as a mechanism to include unbanked segments of the population have been minimal due to industry disinterest. MFIs are presently unregulated in Colombia, and are therefore suited to provide financial services as agents of financial institutions. ${ }^{70}$ The key

\footnotetext{
${ }^{65} I d$. at 19.

${ }^{66} I d$. at 19 (the authors discuss the Banco de Oro in the Philippines, which uses a similar model to manage a prepaid mobile banking platform).

${ }_{68}^{67}$ See infra Part II ("Regulatory Considerations").

${ }^{68}$ Transcript of Virtual Conference Day 2, Session 3: When Should an MFI Considering being an Agent in an mBanking System?, CGAP (Sept. 9, 2010) (transcript on file with author) [hereinafter Transcript Day 2 Session 3]. ${ }^{69} \mathrm{Id}$.

${ }^{70}$ Daniel Mauricio, Alarcon Lozano \& Matteo Mandrile, A New Agent Model for Branchless Banking in Colombia, INT'L LAW DEV. ORG., July 2010, at 4-7, available at http://www.idlo.int/Publications/BranchlessBankingColombia.pdf (in Columbia, the regulatory structure permits financial institutions subcontracting commercial businesses to provide financial services on their behalf. See Decree 2233, which created the NBC provision. NBCs are permitted to provide financial services if acting on behalf of a bank).
} 
determinants in constructing such an arrangement would require both parties to acquire advantages, such as proximity to customers, business opportunities, and financial viability.

To illustrate further, Visionfund Cambodia, an MFI, entered into a partnership with WING, a mobile payments provider, owned by ANZ bank. Pursuant to the partnership, the MFI branches acted as mobile banking agents. ${ }^{71}$ During this venture, divergent interests emerged between MNO and MFI employees. The mobile provider employees derive their compensation through customer acquisition and sales, whereas the MFI employees were salaried, and resultantly, these employees were not as vested in the uptake of WING mobile banking. ${ }^{72}$ Management of both business models should incorporate human resource mechanisms to augment compensation structures in order to minimize conflicting incentives and, develop client acquisition procedures and financial mobilization.

\section{Bank-Led Model}

MFIs, acting as agents of banks, provide services, other than loans, such as adequate liquidity reserves, staff (such as professional and trained employees), savings and checking accounts. $^{73}$ This agent model can be further enhanced if financial institutions extended mobile banking platforms using MFI servicing methods in remote locations. This venture may not only provide access to existing MFI clients, but also capture new customers with limited costs because the mobile banking infrastructure is already operational at the financial institution. This

\footnotetext{
${ }^{71}$ Transcript Day 2 Session 3, supra note 68. See also http://www.visionfund.com.kh/.

72 Transcript Day 2 Session 3, supra note 68.

73 Mauricio, Lozano \& Mandrile, supra note 70, at 11.
} 
can be characterized as a bank-led model as "the bank leads the chain" due to regulatory requirements. $^{74}$

The bank-centric model does not require the cooperation of mobile network operators or hardware manufactures. ${ }^{75}$ The financial institution can develop its own mobile banking system in-house and offer it to its customers. Financial regulators prefer bank-led models as they embody institutional, solvent, and fiscal stability. The partial integration model comprises of a partnership between the financial institution and the mobile network operator. ${ }^{76}$ The third model can be characterized as a joint venture between the financial institution, MNO and a payment system. $^{77}$ The lucrative nature of mobile banking has prompted certain MNOs to acquire banks in order to provide financial services using technology. In Pakistan, only bank-led models are permitted to engage in mobile banking. This motivated Telenor Pakistan, Pakistan's largest telecom operator, to circumvent legislation and acquire a majority share Tameer Microfinance Bank in order to launch Easypaisa, a branchless banking platform. ${ }^{78}$

\section{Consortium Arrangements}

Additionally, proponents of collaborative mobile banking projects believe that a 'consortium model' could provide an ideal business venture for MFIs. ${ }^{79}$ The consortium model

\footnotetext{
${ }^{74}$ Mauricio, Lozano \& Mandrile, supra note 70, at 17 (in Columbia, a bank-led venture is required due to the banking license requirement).

${ }^{75}$ Marc Bourreau \& Marianne Verdier, Cooperation for Innovation in Payment Systems: The Case of Mobile Payment 19 (TELECOM ParisTech Working Paper in Economics and Social Sciences, Working Paper No. 2010-05, 2011), available at $\mathrm{http} / / / \mathrm{economix} . \mathrm{fr} / \mathrm{pdf} / \mathrm{dt} / 2010 / \mathrm{WP} \_E c o X \_2010-05 . p d f$.

${ }^{76} \mathrm{Id}$.

${ }^{77} \mathrm{Id}$.

${ }^{78}$ Chris Bold, Mobile Operators and Banks: If You Can't Beat Them...Buy Them, CGAP TECH. BLOG (Mar. 15, 2010), http://technology.cgap.org/2010/03/15/mobile-operators-and-banks-if-you-cant-beat-them-buy-them/. See also, About Telenor Pakistan, EASYPAISA, http://www.easypaisa.com.pk/index.php/en/about/about-telenor-pakistan (last visited Oct. 8, 2012) (discussing the business structure of the mobile banking platform).

${ }^{79}$ Laura I. Frederick, Information Technology Innovations that Extend Rural Microfinance Outreach, in NEW PARTNERSHIPS FOR INNOVATION IN MICROFINANCE 173, 177 (Ingrid Matthaus-Maier \& J. D von Pischke eds., 2d ed. 2009).
} 
is based on a premise of knowledge-sharing resources from technology, implementation, and enforcement. This model is comprised of private and public sector members, such as MFIs, technology, and financial groups. In managing such collaborative efforts, legal relationships and allocation of liability are clearly defined to articulate how failed transactions or technological problems will be administered. ${ }^{80}$ The collaborative model not only facilitates knowledge sharing, but also reduces substantial business costs for the MFIs. ${ }^{81}$ The preceding approaches discussed are significant as they determine the typology of mobile banking regulation deployed by microfinance institutions.

As governments abandon national telecommunication systems, ${ }^{82}$ public-private partnerships within the microfinance context have emerged. Mobile banking has not only attracted interest from states and development agencies but also private investors, particularly in the mobile telecommunications industry. In order to capture market and industry leaders, host countries hoping to develop telecommunications infrastructure with MFIs must offer legal certainty, fiscal stability, and cooperation. ${ }^{83}$ The high teledensity explosion has created challenges for MFIs and regulators as they address issues ranging from technical alignment, suitable connectivity, and access to electricity or solar charging units. In addition, the deployment of a mobile banking system requires connectivity and access to payment systems.

${ }^{80}$ Id. at 179.

${ }^{81} \mathrm{Id}$.

${ }^{82}$ Sara Corbett, Can the Cellphone Help End Global Poverty?, N.Y. TIMES (Apr. 13, 2008), http://www.nytimes.com/2008/04/13/magazine/13anthropology-t.html?pagewanted=all.

83 "Numerous obstacles have traditionally hindered comprehensive telecommunications infrastructure deployment in developing nations. Construction is halted due to an inability to finance projects. Rugged terrain and/or the remoteness of rural towns and villages complicate logistics and increase expenditures. Labor and transportation costs increase as more time is needed to ship and transfer equipment, to install telephone lines, or to build communications towers in mountainous or rocky areas. As a result, the demand for telecommunications equipment and services considerably exceeds the existing supply. In some nations, civil wars or conflicts have destroyed existing communications lines and towers beyond repair. Ongoing conflicts continue to delay reconstruction. Foreign investors forego projects as markets remain unstable, and regulations, or their enforcement, remain absent. Many governments also resist privatization or the enforcement of transparency and accountability in domestic financial or government institutions." Sandra C. Lee, Wimax in Africa: New Frontier, 15 COMMLAW CONSPECTUS 517, 534-34 (2007). 
Developing markets instinctively use Kenya's M-PESA as a guiding example to embark on mobile banking ventures.

In Ethiopia, however, regulators have been reluctant to permit private investors to enter the mobile banking market due to the underdeveloped regulatory framework. ${ }^{84}$ Ethiopia's Prime Minster, Meles Zenawi, stated that "I(f) they [private telco investors] come in, they (will) use instruments we cannot control...even the best of us do not understand (their instruments, so) how are we are going to regulate these people?" ${ }^{\prime 5}$ The sentiment underlying this statement has resulted in Ethiopia's refusal to liberalize the financial and telecommunications regulatory scheme. Instead, the regulators appear to have adopted a wait-and-see approach.

Currently, it appears that private partnerships have taken the lead in developing mobile banking platforms..$^{86}$ The models that have been discussed function on beneficial relationship between the stakeholders. Regrettably, the consumer is not at the forefront of these arrangements.

\section{Vital Vested Interests}

This profit-driven enterprise of fusing mobile banking with the disbursement of microfinance has also led MFIs to adopt other financial products. MFIs in certain jurisdictions, authorized by its financial regulator, are able to increase profits by offering other financial services and products, such as money transfer services. Remittance services are lucrative and

\footnotetext{
${ }^{84}$ Mercy Kahenda, Ethiopia: Poor, Rural Await Introduction to Mobile Banking, AdDIS FoRTUNE (June 3, 2012), http://allafrica.com/stories/201206060188.html.

${ }^{85} I d$.

${ }^{86}$ Transcript Day 1 Session 2, supra note 49, at 3.
} 
attract new clients, "increase customer loyalty" and allow MFIs to "cross-sell products, such as savings and loans." 87

The transactions costs associated with the transfer of value through branchless banking have also assisted in increasing profit margins of these institutions. Each transaction cost can range from $\$ 0.25-\$ 1.25$, and does not deter customer-usage because customers view this cost as a benefit for incurring a convenience, and in some cases, reducing interest rates of loans. ${ }^{88}$

Similarly, MNOs appear to have a dominant market position given that they may have preexisting relationships with phone manufactures and "control over the distribution of mobile phones." ${ }^{89}$ MNOs also have scalable local retail outlets, which provide services on behalf of MNOs and assist in building brand power. As consumers are exposed to branding and marketing efforts, they gain familiarity and trust with MNOs. Branding power is a large part of creating a 'culture of mobile banking.' This is reinforced through propaganda-type materials, such as television commercials, and billboard and retail advertisements.

Furthermore, the use of "pictorials on flyers, mobile information vans and information disseminated through churches, mosques and durbars of local chiefs and elders" promote mobile banking awareness. ${ }^{90}$ These marketing efforts may initially lead to a surge in subscriber acquisitions, but MNOs and MFIs must continually ensure sustainable usage and maintain visibility. $^{91}$

\footnotetext{
${ }^{87}$ Cerstin Sander, Remittance Money Transfers, Microfinance and Financial Integration: Of Credo, Cruxes, and Convictions, in NEW PARTNERSHIPS FOR INNOVATION IN MICROFINANCE 113, 116 (I. Matthaus-Maier \& J. D von Pischke ed., 2d prtg. 2009) (not all MFIs may offer other products and may require deposit-taking license, banking license etc. to operate).

${ }^{88}$ Kumar, McKay, \& Rotman, supra note 33, at 11.

${ }^{89}$ BOURREAU \& VERDIER, supra note 32, at 20.

${ }^{90}$ Robert Hinson, Banking on the Poor: The Role of Mobiles, 15 J. F. SERV. MKTG., 320, 327 (Feb. 15, 2011).

${ }^{91}$ Ventura et al., supra note 44, at 21.
} 


\section{Mobile Banking in Action}

To facilitate mobile banking deployment, MFIs customarily purchase wireless connectivity from telecommunications carriers and SIM services. ${ }^{92}$ Through this service, only alerts and messages can be transferred. A typical microfinance mobile money transaction consists of a transfer of electronic data from either the MFI or the client, which communicates either a loan or saving transfer, a deposit, or repayment. The whole process resembles a 'relay race' in which commands are communicated by various players to reach the end goal of settlement of funds. ${ }^{93}$

Financial institutions, pursuant to the regulatory framework within the particular jurisdiction, perform the settlement process of funds. Mobile network operators are merely transmitters of information, and consequently deemed to carry content-neutral data. ${ }^{94}$ As such, monitoring and reporting of data may be challenging for MNOs, thereby shifting the regulatory compliance to MFIs. Compliance requirements may vary based on each jurisdiction, and can encompass record keeping, reporting and monitoring standards. ${ }^{95}$

\section{Collection Practices}

Traditionally, a loan officer from the MFI processes the collection of loan repayments at the customer's residence or during group meetings. The introduction of mobile banking has transformed individual and group collection methods. Group meetings, which may be a part of the loan conditions, have also been impinged as a result of branchless banking. ${ }^{96}$ Repayment methodology of individual and group loans differ in that individual customers can remit their

\footnotetext{
${ }^{92}$ Mas \& Kumar, supra note 15 , at 19.

${ }^{93}$ CHATAIN ET AL., supra note 22.

${ }^{94} I d$.

${ }^{95} \mathrm{Id}$.

${ }^{96}$ Mark Pickens, When is Mobile Banking Not Banking?, CGAP (Nov. 19, 2007) (on file with author).
} 
loan payment using SMS text messaging, and use the return confirmation notice as a receipt of payment. $^{97}$

Group loans are also required to present confirmation notices as proof of repayment; each member physically presents to the loan officer the amount of repayment and the confirmation message. ${ }^{98}$ These confirmation notices are either uploaded electronically to the MFI ledger or used to physically crosscheck payment at meetings. ${ }^{99}$ The loan officer oversight is removed through the digital monitoring process, thereby creating a balanced and non-coercive environment. $^{100}$

These methods function as internal controls within the institution and systematically build consumer payment history. ${ }^{101}$ Repayment history is a valuable commodity for MFIs by demonstrating creditworthiness of its customers, and further curing the existing information asymmetry. This usage operates as an informal credit rating bureau for MFIs. ${ }^{102}$

Repayment of loans using mobile banking has dramatically reduced transaction costs for MFIs, as physical deployment of loan officers to embark on collection efforts is no longer necessary. However, customers may have to pay a service charge in using mobile banking for repayment purposes. In 2009, a microfinance institution in Kenya called Small and Micro Enterprise Programme (SMEP), used the already existing M-PESA platform for repayment services. ${ }^{103}$ SMEP's challenges included a shortage of agent e-floats, thereby causing loan

\footnotetext{
${ }^{97}$ Transcript Day 2 Session 3, supra note 68.

${ }^{98} I d$.

${ }^{99} \mathrm{Id}$.

${ }^{100} I d$. at 5.

${ }^{101} I d$. at 9 .

${ }^{102} \mathrm{Id}$.

${ }^{103}$ Transcript Day 2 Session 3, supra note 68.
} 
disbursement problems. ${ }^{104}$ Solutions may include using past practices to measure the amount of funds required on a daily basis.

Furthermore, the duration of group lending meeting times decreased from three hours to twenty minutes, thus improving the efficiency of financial services. ${ }^{105}$ However, as consumers became familiar with electronic repayment, their attendance to group meetings diminished. As a result, the SMEP implemented a tiered meeting schedule to promote attendance to meetings, such as permitting consumers who made timely payments to attend fewer meetings and utilize their repayment history to "qualify for the next loan."106 As demonstrated by this case study, the use of mobile banking in repayment practices not only alters user experience, but it also promotes norm setting standards that are easily developed and implemented to address isolated challenges.

\section{Part II: Regulatory CONSIDERATIONS}

"What can governments do to foster m-banking? As with the spread of mobile phones themselves, a lot depends on putting the right regulations in place. They need to be tight enough to protect users and discourage money laundering, but open enough to allow new services to emerge. The existing banking model is both over- and under-protective, says Tim Lyman of the World Bank, because "it did not foresee the convergence of telecommunications and financial services."107

Mobile Banking's unique structure has evolved and now occupies both the banking and telecommunications regulatory space. Due to its fluid innovative status, regulators in both industries have struggled to enact adequate legislation specifically applicable to mobile banking

\footnotetext{
${ }^{104}$ Id. at 2.

${ }^{105} I d$. at 4 (discussing how this process eradicated fraud, error free, and transparent process). ${ }^{106}$ Id.

${ }^{107}$ Mark Pickens, When is Mobile Banking not Banking?, CGAP (Nov. 19, 2007), available at http://technology.cgap.org/2007/11/.
} 
transactions. The fundamental principles underlying regulation are to minimize and contain systematic risks within the industry.

Core risks within mobile banking are based on its "anonymity," "rapidity" and "poor oversight." 108 Simply put, regulation and governance discourse generally centers on who may engage in a specific activity and what constitutes regulated or unregulated activity. This is especially true in financial regulation.

Regulation of mobile banking in the context of microfinance can be evaluated through several lenses: either by examining the provider's role, or the services, or transaction it is engaged in. Not all microfinance institutions are created equally; the evolution of MFI regulation shares a parallel reality with the development of mobile banking in that they are both growing in fragmented form. ${ }^{109}$ Whether an MFI is regulated in its institutional capacity is dependent on jurisdictional requirements, which may require deposit-taking MFIs to be licensed as banks or non-bank financial institutions. ${ }^{110}$

Even though unregulated MFIs may operate outside the purview of regulatory oversight, they may have reporting requirements, ${ }^{111}$ which may affect how its mobile banking platform is designed and developed. Furthermore, partnerships between MNOs and MFIs may be scrutinized by the regulator. The regulatory variables can be endless; how MFIs structure their mobile banking deployment may be subject to specific regulation depending on the jurisdiction.

Banking regulators are primarily concerned about the stability and the integrity of the financial system, and thus, they have resisted embracing new market entrants, such as the

\footnotetext{
${ }^{108}$ CHATAIN ET AL., supra note 22, at preface.

${ }^{109}$ As there is no uniform standard applicable to show the development of regulation, each MFI is regulated by its jurisdiction at its own pace.

${ }_{110}$ In Uganda, MFIs are regulated.

111 Again, these depend on the organizational status of the MFI. For instance, banks and certain credit unions have reporting requirements depending on the jurisdiction.
} 
telecom industry. For instance, in 2008, during the successful deployment of M-PESA, Kenyan banks urged the Central Bank of Kenya to investigate Safaricom and M-PESA, "labeling it 'nothing more than a Ponzi Scheme."”112 As mobile banking has become an essential component in delivering financial services, financial regulators are faced with numerous challenges. In addition to monitoring consumer protection concerns, regulators must also address legal issues surrounding cash handling, anti-money laundering ("AML) and counter terrorist financing (“CFT") measures, deposit-taking, and the issuance of electronic money.

\section{A. Providers of Mobile Banking}

Mobile banking service providers take many forms; they can be traditional banks, telecom companies, mobile operators, NGO-MFIs or For-Profit MFIs. Due to the sudden eruption of mobile banking platforms in emerging economies, regulators have sought to create or use existing legislation to oversee these providers by either regulating the entity or the activity. In providing access to financial services, a critical regulatory issue is whether companies, which engage in mobile services, may also provide financial services.

Regulators in Kenya and in the Philippines have permitted mobile service providers to sell financial products without banking licenses. ${ }^{113}$ The delineation of the regulatory structure underpinning mobile banking requires an examination of the factors affecting MFIs, mobile operators, and consumers. The applicable regulatory framework can be categorized as being provider-targeted or service-targeted. ${ }^{114}$

\footnotetext{
${ }^{112}$ Gary Collins, The Real Reason why Kenya's M-Pesa Won't Work Anywhere Else, MonEYWeB (Sept. 1, 2011), http://www.moneyweb.co.za/moneyweb-soapbox/the-real-reason-why-kenyas-mpesa-wont-workanywher?sn=2009+Detail.

${ }^{113}$ Mas \& Kumar, supra note 15 , at 25 (deposit-taking is regulated by the banking regulator. In this context, the definition of "deposit" hinges on whether a transaction falls under regulatory purview or not).

${ }^{114}$ ChatAin ET AL., supra note 22.
} 
In bank-based models of mobile banking, a prudentially supervised entity underwrites the mobile banking process. Conversely, customers do not have a "direct or contractual relationship" with a financial institution in nonbank-based models. ${ }^{115}$ As non-bank based models operate beyond the scope of the regulatory framework, regulators have attempted to regulate the activity, rather than the provider. Certain jurisdictions only permit banks in engaging in the delivery of mobile banking. Alternatively, they may impose constraints on outsourcing certain segments of mobile banking.

To date, electronic banking, electronic money and payment systems legislation promulgated by regulators have attempted to address the gaps in regulatory oversight by supervising the issuance of electronic money, access to payment systems, and rights and obligations in electronic banking transactions.

In Sri Lanka, the Central Bank of Sri Lanka (CBSL) regulates m-banking activity pursuant to the "Payment and Settlement Systems Act of 2005." 116 The CBSL further requires mobile service providers to be licensed, to have an arrangement with a custodian bank, and to be compliant with national legislation with respect to consumer protection, agent relationships, and electronic money. ${ }^{117}$

Sri Lanka's mobile banking regulation is emblematic of the regulatory approach employed in emerging economies in a bank-led mobile banking model. In the context of regulation, specific to mobile banking deployed by MFIs, the regulatory oversight would be extended to the type of business model used to facilitate mobile banking. For instance, the

\footnotetext{
115 Timothy R. Lyman, Mark Pickens \& David Porteous, Regulating Transformational Branchless Banking: Mobile Phones and Other Technology to Increase Access to Finance, CGAP (Jan. 2008), available at http://www.paymentsnews.com/2008/01/regulating-tran.html.

${ }^{116}$ Rasheda Sultana, Mobile Banking: Overview of Regulatory Framework in Emerging Markets, 4TH COMM. POL'Y RES., S. CONF., NEGOMBO, SRI LANKA, Dec. 8, 2009, at 8, available at http://ssrn.com/abstract=1554160.

${ }^{117}$ Mobile Payments Guidelines No. 2 of 2011 for Custodian Account Based Mobile Payment Services, CENT. BANK OF SRI LANKA, http://www.cbsl.gov.lk/pics_n_docs/09_lr/_docs/directions/psd/14_mobile_payment_2011_2e.pdf (last visited July 27, 2012).
} 
regulatory oversight would depend on whether MFIs collaborate with a telecommunications company or a bank.

In both business models, the financial or telecommunications regulator determines the appropriate standards. The extension of regulation reaches not only mobile banking providers, transactions and activities, but also partnerships and relationships of service providers. This is especially true when MFIs use third party intermediaries, such as non-bank entities, to deliver mobile banking services.

\section{B. Be An Agent or Use An Agent?}

The 'agent' is a central theme in the mobile banking discourse. The agent can be characterized as an intermediary or facilitator in delivering financial services to enhance financial inclusion. ${ }^{118}$ The agent is perfectly situated to deliver services in remote areas and to the unbanked segment of the population due to their proximity within the community, ${ }^{119}$ and existing relationships. Agent banking has been attributed to the fiscal improvement of institutions that deliver mobile banking services. ${ }^{120}$

The agent relationship can be manifested through various business models, such as between the MFI and the bank, or the MNO and the MFI, or the MFI on behalf of a bank. These business configurations bear a myriad of regulatory variables in regulating banking agents.

Many jurisdictions have developed legislative measures to address the eligibility and requirements of agents. The Reserve Bank of India permits the use of two categories of agents:

\footnotetext{
118 The term "agent" is used to "refer to any third party acting on behalf of a bank (or other principal), whether pursuant to an agency agreement, or other similar arrangement." Kate Lauer et al., Bank Agents: Risk Management, Mitigation, and Supervision, CGAP, at 3 (Dec. 2012), available at http://www.cgap.org/sites/default/files/FocusNote-Bank-Agents-Risk-Management-Mitigation-and-Supervision-Dec-2011.pdf.

${ }^{119}$ Clara Veniard, How Agent Banking Changes the Economics of Small Accounts, GlOBAL SAVINGS FORUM (Nov. 2010), http://www.gatesfoundation.org/financialservicesforthepoor/Documents/agent-banking.pdf. ${ }^{120} \mathrm{Id}$.
} 
(1) business correspondents and (2) business facilitators as 'agents.'121 Business facilitators, however, serve as administrators and cannot engage in any banking activities. These business facilitators may assist in financial literacy initiatives, collect data, and assist in collecting loan applications. $^{122}$ Financial entities are permitted to use business correspondents to 'outsource' certain functions to these agents. ${ }^{123}$ This includes allowing business correspondents to provide small value credit and remittance services, in addition to all administrative functions required to provide financial services. $^{124}$

In India, post offices, MNOs, shop owners, and retired teachers are allowed to be agents. ${ }^{125}$ However, for-profit MFIs, which are registered as nonbank finance companies, are not permitted to be agents. ${ }^{126}$ Furthermore, in India, business correspondents additionally serve as microfinance recovery agents; their recovery methods have become controversial as a result of the 2010 microfinance crisis in Andhra Pradesh. ${ }^{127}$ This prompted the RBI and the state

\footnotetext{
${ }^{121}$ Lauer et al., supra note 119 , at 3.

122 Id.

${ }^{123}$ Guidelines for Engaging of Business Correspondents, THE RES. BANK OF INDIA (2010), http://rbi.org.in/scripts/NotificationUser.aspx?Id=6017\&Mode=0. These guidelines permit: "[t]he scope of activities may include (i) identification of borrowers, (ii) collection and preliminary processing of loan applications, including verification of primary information/data, (iii) creating awareness about savings and other products and education and advice on managing money and debt counseling, (iv) processing and submission of applications to banks, (v) promoting, nurturing and monitoring of self-help groups/joint liability groups/credit groups/others, (vi) post-sanction monitoring, (vii) follow-up for recovery, (viii) disbursal of small value credit, (ix) recovery of principal/collection of interest, (x) collection of small-value deposits, (xi) sale of micro insurance/ mutual fund products/ pension products/ other third party products, and (xii) receipt and delivery of small value remittances/ other payment instruments." See also Ramesh Arunchalam, The Need for Due Diligence for Business Correspondents Who Deliver Financial Services to Low Income People, MONEY LIFE (Sept. 19, 2011), http://www.moneylife.in/article/the-need-for-due-diligence-for-business-correspondents-who-deliver-financialservices-to-low-income-people/19840.html.

${ }^{124}$ Lauer et al., supra note 119 , at 3.

${ }^{125}$ Michael Tarazi \& Paul Brelof, Regulating Banking Agents, CGAP (Mar. 2011), http://www.cgap.org/publications/regulating-banking-agents.

${ }^{126} I d$.

127 The Andhra Pradesh Crisis is also commonly known as the Microfinance Suicides. Soutik Biswas, India's Micro-Finance Suicide Epidemic, BBC NEws SOUTH ASIA, Dec. 16, 2010, http://www.bbc.co.uk/news/world-south-asia-11997571.
} 
government to issue directives in employing due diligence in selecting business correspondents. ${ }^{128}$

Conversely, in Kenya, only for-profit institutions are permitted to be agents. The underlying policy of disallowing non-profit entities to perform banking agent duties is based on ensuring that nonprofit institutions only engage in social operations. ${ }^{129}$ Therefore, these examples of agency models, suggest that an NGO-MFI in Kenya cannot be an agent of a financial institution, but may hold that role in India. ${ }^{130}$

The functions of a banking agent in certain jurisdictions are subject to regulatory supervision. Vital components in deploying mobile banking services include cash handling, cash management, loan extensions, loan repayment collection and remittance transfers. ${ }^{131}$ Each of these services may have different regulatory implications. The singular function of cash handling includes verification of customer identification in compliance with AML/CFT legislation, the adequacy of documentation and the acceptance of cash (also known as "cash in services"), the issuance of e-money and agent supervision. ${ }^{132}$ A recent study revealed that " 4 in 10 countries permit banks to use agents." 133

Furthermore, "a majority (of countries) permit agents to handle deposits (65\%) and a sizable minority permits them to conduct a know-your-client inquiry KYC to open accounts (32\%). Countries where regulation restricts MNOs to carrying data and where agent restrictions

\footnotetext{
128 Arunchalam, supra note 124.

${ }^{129}$ Tarazi \& Brelof, supra note 126, at 2.

${ }^{130}$ See Point 4, Bank Supervision, CENTRAL BANK OF KENYA, http://www.centralbank.go.ke/index.php/banksupervision\#commercial-banks (last visited Oct. 13, 2012).

${ }^{131}$ Tarazi \& Brelof, supra note 126, at 3.

${ }^{132}$ Id. at 5.

${ }^{133}$ Stephen Rasmussen, The Hype Cycle and Mobile Banking, CGAP (June 23, 2009), http://technology.cgap.org/technologyblog/wp-content/uploads/2009/06/hype-cycle-and-mobile-banking.pdf.
} 
stunt viability are the exception."134 The regulatory shift is illustrative of how legislation has adapted to the new emergence of new entrants in the financial marketplace.

In a Post-911 climate, legislative measures on a global scale have been implemented to combat terrorist financing and money-laundering. ${ }^{135}$ As such, determining accurate customer identity with Know-Your-Client (KYC) guidelines, traceability of funds, and transaction limits have become indispensable ingredients in regulatory compliance. ${ }^{136}$ The verification of customer identification is typically performed by the MFI through its internal process. However, if subcontracting the customer due diligence process to a non-bank entity, it must be in conformance with the national regulatory regime. In some instances, agents may assist in loan application processing, credit verification, and account inquiries, thus blurring the distinctions of regulated functions by nonbanks. ${ }^{137}$

Certain jurisdictions only permit retail agents to undertake KYC procedures on low-level transactions. These jurisdictions may also impose subcontracting constraints. For instance, agents in India, Brazil, and Colombia, may subcontract KYC procedures if prior consent is obtained from the financial institution. ${ }^{138}$ In contrast, Kenya does not permit an agent to delegate customer verification procedures. Therefore, in a non-bank led MFI-MNO partnership, the use of retail agents must be in jurisdictional conformance of the regulatory requirements. Similarly, in a bank-led MFI- agent model, a NGO-MFI acting on behalf a bank may not be able to perform all agent functions in a jurisdiction like Kenya. ${ }^{139}$

\footnotetext{
${ }^{134} I d$.

${ }^{135}$ Tarazi \& Brelof, supra note 126, at 4 (the Financial Action Task Force (FATF) develops international standards to combat money laundering and terrorist financing).

${ }^{136}$ Michael Tarazi \& Paul Brelof, Regulating Banking Agents, CGAP (Mar. 2011), http://www.cgap.org/publications/regulating-banking-agents.

${ }^{137}$ Lauer et al., supra note 122 , at 3.

138 Tarazi \& Brelof, supra note 126, at 11-13.

${ }^{139}$ Bank Supervision: Agent Banking, CENTRAL BANK OF KENYA, http://www.centralbank.go.ke/FAQs/BankSupervisionFAQs.aspx\#tab1 (last visited Nov. 3, 2012) ("In Kenya, agent
} 


\section{Cash In or Deposit-Taking?}

The second tier in agent banking is the cash handling function. The "cash in/cash out" service creates legal uncertainty with respect to 'deposit-taking' activity. The act of deposittaking is regulated by the financial regulator and may require licensing. ${ }^{140}$ Deposit-taking is a highly regulated activity pursuant to prudential regulation. ${ }^{141}$ In order to facilitate banking agent services, jurisdictions have attempted to circumvent these requirements by permitting agents in accepting customer funds for mobile banking services and loan repayments by imposing low transaction limits and cash handling procedures. For instance, business correspondents in India, "may engage in disbursal of small value credit... receipt and delivery of small remittances/ and other payment instruments." ${ }^{\prime 142}$ The characterization of the acceptance of small sum customer funds appears to change the legal nature of deposits. These small sum funds do not constitute 'deposits,' as the deposit-taking regulatory scheme is not triggered by this type of agent activity thereby permitting non-bank entities to accept 'payment' of this nature. Pursuant to the Central Bank of Kenya, M-PESA customer funds, which are held in trust accounts at commercial banks, are not considered deposits. The interest accrued on funds held by commercial banks as a result of the trust relationship is conveyed to charity. ${ }^{143}$

In order to further develop regulatory clarity regarding who may accept deposits or engage 'in the business of banking,' jurisdictions such as, Uganda and Kenya, have developed a regulatory framework, specifically designed to pull specific MFIs within the regulatory ambit. Pursuant to "The Microfinance Act" enacted in Kenya, MFIs intending to accept deposits from

banking is governed by the Prudential Guideline on Agent Banking issued by the Central Bank and which became operational on 1st May 2010.”).

${ }^{140}$ Tarazi \& Brelof, supra note 126, at 3.

${ }^{141}$ Deposit-taking encompasses acceptance of consumer funds, and using those funds for lending and investment purposes. Banking principles perceive this activity as high risk, thereby stringent regulations are imposed.

${ }_{142}$ Tarazi \& Brelof, supra note 126 , at 13.

${ }^{143}$ Klein \& Mayer, supra note 7, at 9. 
the public must be licensed and will be regulated by the Central Bank of Kenya. ${ }^{144}$ Similarly, Uganda passed "The Microfinance Deposit-taking Institutions (MDI) Act" in 2003. ${ }^{145}$ By regulating deposit-taking MFIs, regulators in Kenya and Uganda have succeeded in conforming to fundamental banking policies, yet permitting non-bank agents to engage in low level acceptance of consumer funds during the operation of mobile banking.

\section{Who Can Issue E-Money during M-Banking?}

Not only has mobile banking caused deposit-taking activities to be scrutinized by national regulators, but it has also raised the issue of disbursement of electronic money by non-bank agents. To date, emerging economies are attempting to clarify banking agent regulations, and are also striving to develop "legal boundaries between retail payments, e-money, and other stored-value instruments and bank deposits." ${ }^{146}$ The definition of electronic money in the Philippines is defined as a "monetary value as presented by a claim on its issuer that is electronically stored in an instrument or device, (ii) issued against receipt of funds of an amount not lesser in value than the monetary value issued, (iii) accepted as a means of payment by persons or entities other than the issuer, (iv) withdrawable in cash or equivalent.",147

\footnotetext{
${ }^{144}$ Bank Supervision, CENT. BANK OF KENYA (2006), http://www.centralbank.go.ke/index.php/banksupervision\#deposit-taking-microfinance-institutions (Kenya has yet to issue legislation on Non-deposit taking MFIs).

${ }^{145}$ Uganda Micro Finance Act 5 Deposit-Taking Institutions Act 2003 (May 2, 2003), available at http://www.bou.or.ug/export/sites/default/bou/boudownloads/acts/supervision_acts_regulations/MDI_Acts/MDIAct2003.pdf.

${ }^{146}$ Lyman, Pickens \& Porteous, supra note 116, at 2.

${ }^{147}$ Circular No. 649, THE CENT. BANK OF THE PHIL. (Mar. 2009) available at http:/www.bsp.gov.ph/downloads/Regulations/attachments/2009/c649.pdf. Note also, that the European Union's definition of electronic money "means electronically, including magnetically, stored monetary value as represented by a claim on the issuer which is issued on receipt of funds for the purpose of making payment transactions as defined in point 5 of Article 4 of Directive 2007/64/EC, and which is accepted by a natural or legal person other than the electronic money issuer." Council Directive 2009/110, art. 2, 2009 O.J. (L 267) 7, 11 (EC).
} 
The process during the mobile banking transaction can be characterized as the "electronification"148 of cash, which creates an electronic value of record. ${ }^{149}$ Expressly, e-money "is an electronic surrogate for coins and banknotes." ${ }^{150}$ During the receipt of cash, the agent converts the customers' money into a prepaid stored value. The conversion of cash into a prepaid instrument has created regulatory challenges as it is intrinsically linked to deposit-taking, thereby precluding certain agents from engaging in the issuance of electronic money. However, jurisdictions, such as the Philippines, have issued circulars deeming that e-money is not a 'deposit,' and that the issuance of electronic money does not constitute deposit-taking. ${ }^{151}$ Whether MFIs, who are engaged in mobile banking, are considered issuers of e-money and are subject to this demarcation of the terminology discussed above, is dependent on their regulatory status and the national regulator.

\section{E. Who is Liable?}

The use of agents precipitates the issue of liability between stakeholders. Agent liability is imposed by common law, contract law or statutory enactment. Brazil and India impose liability on banks for the use of agents. ${ }^{152}$ Liability in mobile banking can arise as a result of

\footnotetext{
${ }^{148}$ Citation to the term used, but not citing the idea of the article. Robert McGarvey, Report: The Mobile Payments Explosion, CREDIT UNION TIMES (Sept. 16, 2011), http://www.cutimes.com/2011/09/16/report-the-mobilepayments-explosion.

${ }^{149}$ Lyman, Pickens \& Porteous, supra note 116, at 3.

${ }^{150}$ Understanding Financial Regulation and How it Works, GSMA MOBILE MONEY TRANSFER, at 8 (Sept. 2008), available at http://www.gsma.com/mobilefordevelopment/wpcontent/uploads/2012/06/gsmaunderstanding_financial_regulation_0908.pdf. ${ }^{151}$ Circular No. 649, THE CENT. BANK OF THE PHIL. (Mar. 2009) available at http://www.bsp.gov.ph/downloads/Regulations/attachments/2009/c649.pdf

152 Tarazi \& Brelof, supra note 126, at 9. See also Denise Dias \& Katharine McKee, Protecting Branchless Banking Consumers: Policy Objectives and Regulatory Options, 64 CGAP FOCUS NOTE 10 (Sept. 2010), available at http://www.cgap.org/sites/default/files/CGAP-Focus-Note-Protecting-Branchless-Banking-Consumers-PolicyObjectives-and-Regulatory-Options-Sep-2010.pdf ("Brazilian regulation, for example, holds financial firms 'fully responsible for services provided by agents.' The Colombian regulation is more precise and holds the provider "fully responsible to the client, for services offered to the agent."). The distinction demonstrates a double layer of liability,
} 
misdirected funds, transmission errors, forgery or fraud, and negligence. Agency theory, therefore, provides redress as a mechanism.

Licensed MFIs, who are using agents in delivering mobile banking services, may be liable for the acts or omissions of their banking agents; or conversely, MFIs, acting as agents on behalf of banks, may be alleviated from any liability. The imposition of bank liability on financial institutions gives "regulators the comfort" in permitting the use of agents as it fosters prudential regulatory policy. ${ }^{153}$ MFIs, regulated by the financial regulator, in selecting agents may then opt for less risky partnerships by considering the solvency, durability and market participation of the agents to minimize liability. Proponents for financial inclusion argue that the imposition of bank liability may in fact be an impediment to financial access, as costs associated with mitigating risks will be incurred by the service provider, which will impact the customer. ${ }^{154}$ Consequently, it is argued that regulators impose only limited liability on financial institutions with respect to the agents' provision of financial services in order to reduce overall costs. Indemnification clauses in agency agreements are encouraged by stakeholders, whereby agents have a duty to indemnify financial institutions, and/or preclude agents from holding themselves out as a bank. ${ }^{155}$

Microfinance institutions can shield themselves from liability by engaging in low risk arrangements and ensuring that their partnerships facilitate secure and reliable mobile banking services. In conjunction with ensuring that providers of mobile banking services are subject to

not only is the agent liable, but also the principal provider. $I d$. Therefore, both entities may be joint and severally liable. $I d$. This is another way to minimize risks within mobile banking deployment. Id. Also note, that in Kenya, Safaricom is not subject to "legal liability for the acts of M-Pesa agents" or consumer protection legislation. Id. Its business practices, however, dictate that the interests of consumers are protected to some extent, as trust and integrity of the mobile banking platform are essential for its financial viability. Id.

${ }^{153}$ Tarazi \& Brelof, supra note 126 , at 9.

${ }^{154} \mathrm{Id}$.

${ }^{155}$ Lyman, Pickens \& Porteous, supra note 116, at 8. 
regulatory oversight, national regulators have attempted to ensure that access to payment systems are not compromised by new market entrants.

\section{F. Payment Systems}

Access to payment systems is a significant component in delivering financial services through mobile banking. Success in mobile banking is rooted in the fact that the MFIs must be members of an electronic payment platform if deploying scalable branchless banking. ${ }^{156}$ Due to fast-paced convergence of business, information technology, and financial services, the underlying continual question is whether non-bank entities can share the space previously only reserved for banks. This is particularly an issue for MFIs, as access to national payments system is met with regulatory roadblocks. Even when an MFI possesses a commercial bank license, it does not automatically guarantee access to national payments systems. ${ }^{157}$ As a result, MFIs are compelled to create special arrangements with commercial banks to gain access to the national payment system. ${ }^{158}$

Smaller and unlicensed MFIs lack access to payment systems so, they are unable to provide their customers with additional services, such as checking accounts. ${ }^{159}$ Despite impediments to payment system entries, central banks in emerging economies have broadened access to financial infrastructure to further financial inclusiveness. The Reserve Bank of Malawi

\footnotetext{
${ }_{156}^{156}$ Ivatury, supra note 2, at 149 n.10.

${ }^{157}$ Payments and Infrastructure, CGAP, http://www.cgap.org/topics/payments-and-infrastructure (last visited July 27, 2012).

${ }^{158} \mathrm{Id}$.

${ }^{159}$ Patricia Mwangi, Financial Market Infrastructure in the Sub-Saharan, CGAP, http://www.ebookxp.com/f13072cae8/Financial+Market+Infrastructure+in+Sub-Saharan+Africa.html (last visited July 27, 2012).
} 
developed the Malawi Switch Center (MALSWITCH), which is a national payment system platform for all financial institutions, including MFIs and non-banks. ${ }^{160}$

Within the mobile banking context, payment systems are vital ingredients in the electronic payments process. "Electronic payments are a form of disruptive technology that has the potential to make cash and checks obsolete, thus changing the structure of the payments industry." 161 The payment system's value is based on its reliability, security, integrity and efficient real time payment processing. In developed nations, "the industry is shaped by its share of entry and exit" and not solely by the regulator. ${ }^{162}$ Similarly, emerging markets are still grappling with legislating payment system regulations to meet the increasing speed of innovation and the possibility of cross-border transactions. Electronic payment system regulations must be in place to ensure enforceability and validity of transactions. The integrity of payment systems is heavily dependent on networks of arrangements, which transfer the value. In an MFI-led mobile banking deployment structure, access to a payment system must encompass interoperability, technical infrastructure, security protocols, and modernization features.

As MFIs gain gradual access to payment systems, regulatory oversight will be shaped by central banks to mitigate risks as a result of new entrants into the payments space. Mobile banking can be perceived as a technological innovation, which has affected the status quo in effect. As such, regulations and new policies to foster pragmatic solutions are being developed for vertical and horizontal integration within the payments systems infrastructure. ${ }^{163}$ In

\footnotetext{
${ }^{160}$ One Continent, Many Solutions, CGAP (Oct. 2006), http://wwwwds.worldbank.org/servlet/WDSContentServer/IW3P/IB/2007/01/26/000020439_20070126092613/Rendered/PDF/ 384080CGAP0Portfolio10501PUBLIC1.pdf.

${ }^{161}$ Richard Sullivan \& Zhu Wang, Nonbanks in the Payments System: Innovation, Competition, and Risk - A Conference Summary, ECON. REV. 83, 86 (2007), available at http://www.kc.frb.org/PUBLICAT/ECONREV/PDF/3q07sullivan.pdf.

${ }^{162} \mathrm{Id}$. at 83 .

${ }^{163} \mathrm{Id}$.
} 
particular, this trend has catapulted new ventures, such as new software and technology to support mobile banking within the microfinance context.

For instance, FrontlineSMS has developed mobile technology software specifically for non-profit organizations. The software turns a computer and a mobile phone into a "two-way group messaging hub."164 The process is comprised of exchanging text messages, which operates on a mobile signal and does not require internet access. ${ }^{165}$ This technology has been expanded as 'FrontlineSMS-Credit' to assist microfinance institutions in delivering loans and accepting payments electronically. ${ }^{166}$ This specific technology requires MFIs to have an account with a mobile payment system in order to link the financial institution to the wireless output. "The new venture is building a series of free and open source financial modules that will allow FrontlineSMS to communicate with mobile payment systems in real time" and promises to enhance the institution's internal operations. ${ }^{167}$

\section{G. Security Solutions \& Liability for Losses}

Security concerns are paramount for mobile network operators in order to ensure data integrity, connection reliability and customer privacy. Despite consumer apprehension with respect to any form of electronic banking, mobile banking appears to be "inherently safer" than

\footnotetext{
${ }^{164}$ Ken Banks \& Benjamin Lyon, CreditSMS Helps Structure Informal Mobil Finance, PC WorLD (Aug. 11, 2009), http://www.goodgearguide.com.au/article/314379/creditsms_helps_structure_informal_mobile_finance/. 
internet or online banking. ${ }^{168}$ This is partly due to the physical features built into a mobile handset, such as the phone number and the manufacturer's serial number. ${ }^{169}$ If the handset is lost or stolen, the telecommunications carrier can geographically track the mobile phone, and cancel the service. ${ }^{170}$ However, the leading threat to mobile banking remains data theft through fraud or malware.

The mobile banking platform, which is carved into two components: (1) the subscriber identification module (front-end) and (2) settlement (back-end), is susceptible to external threats, such as hacking or data theft. The SIM encryption maintains the integrity of the system and the mobile phone will only function with a valid SIM card. ${ }^{171}$ Industry insiders have argued that only a telecom-led business model can provide "full control" as the SIM is controlled by the mobile network operator. ${ }^{172}$ Further, the authentication process of the subscriber is a vital component in the transaction as it is designed to protect the network against threats. ${ }^{173}$

Authentication preserves data confidentiality; its main function is to 'identify' and 'verify., 174 "Identification is a process by which an entity claims a certain identity while verification involves checking the claim." 175 Authentication can take many forms and can be characterized as follows:

\footnotetext{
${ }^{168}$ Frederick M. Joyce, Mobile Banking Liability: The Elephant in the Parlor, THE INNOVATOR, at 8 (Nov. 2010), available at http://www.venable.com/files/Publication/2c272822-9cb5-4715-921881eae2cec549/Presentation/PublicationAttachment/c02adbe1-6b83-4def-8146-84648b9d0999/Innovator_Nov10.pdf.

${ }^{169}$ Id. at 29.

${ }^{170} \mathrm{Id}$.

171 Abunyang Emmanuel, Mobile Banking in Developing Countries: Secure Framework for Delivery of SMSBanking Services (Aug. 2007) (unpublished manuscript), available at http://masalai.files.wordpress.com/2009/03/sms-bank-in-developing-countries.pdf.

${ }^{172}$ Paul Makin, Regulatory Issues Around Branchless Banking, ORGANISATION FOR ECONOMIC CO-OPERATION AND DEVELOPMENT, at 11, available at http://www.oecd.org/ict/4d/44005585.pdf (last visited July 27, 2012).

${ }^{173}$ Emmanuel, supra note 172 , at 11 .

${ }^{174} I d$. at 19.

${ }^{175}$ Id.
} 
(1) Proof by knowledge "where the claimant demonstrates knowledge of some information regarding the claimed identity that can be known or produced by a principal with the claimed identity. Some good examples that demonstrate proof of knowledge are typing of a password or computing replies to challenges by a verifier"176;

(2) Proof by possession "where the claimant produces an item that can only be possessed by a principal with the claimed identity",

(3) Proof by property. "A good example of this approach is use of biometric techniques for authentication like the fingerprint, retina print etc. The verifier measures this claimant's properties."178

Even though authentication plays a significant role in mitigating security risks within the mobile banking process, a threat of interception, hacking or information leakage and data theft are a constant concern for MNOs. In particular, protecting consumers' account and PIN numbers is of utmost importance in preventing banking fraud. ${ }^{179}$ Stakeholders, such as banks and MNOs, mutually share security measures and costs, however, MFIs do not participate in this effort (unless they are deemed to be financial institutions) at this time. As more MFIs use mobile banking platforms to deliver financial services, their role as actual stakeholders must be recognized. Their input in security protocols should be part of these integrated discussions, as their customers are the most vulnerable and have the most to lose. The success of the mobile banking platform depends on the strength of security implemented within the system. ${ }^{180}$

Furthermore, many jurisdictions, such as Cote D'Ivoire, Ghana and South Africa, have imposed mandatory SIM registration requirements to combat money laundering and terrorist financing. This process eliminates the 'anonymity factor' when employing mobile banking, but

\footnotetext{
${ }^{176} I d$. at 20 .

${ }^{177}$ Id. at 23

${ }^{178} \mathrm{Id}$.

${ }^{179}$ Emmanuel, supra note 172 , at 26.

${ }^{180}$ Bossi Masamila et al., A Secured Mobile Payment Model for Developing Markets, in NETWORKED DIGITAL

TEChNOlogies, COMMUNiCATIONS IN COMPUTER AND INFORMATION SCIENCE 87, at 179 (2010).
} 
as a result, the number of subscribers has decreased. ${ }^{181}$ This may not be a challenging aspect for MFIs, as SIM card registration can be imposed as a condition for receiving financial services, thereby also assisting in creating an electronic record for each customer.

Telecommunications carriers and manufacturers have combined efforts to create standardized security initiatives to prevent fragmentation of protection within the transactional process. ${ }^{182}$ In developed markets, telecom manufacturers, including Ericsson, Motorola, and Nokia, have been part of harmonization efforts to create a common framework for industry security requirements. ${ }^{183}$

However, developing markets have struggled to create a cohesive security structure due to various new players in the mobile banking space, which have affected the security in end-toend transactions. ${ }^{184}$ Standardization of security protocols are imperative for MFIs and their consumers, as the entire transactional system is reliant on the integrity of the mobile banking platform. Therefore, the security strategies should encompass a harmonized effort between all stakeholders from telecom manufacturers and carriers, financial institutions (banks and MFIs), and consumer advocates.

Security of customer data and privacy are often regulated in the consumer protection context. Industry regulators act in concert and are charged with overlapping oversight with mobile banking security measures. However, in certain jurisdictions, security protocols and customer data is governed under the purview of the telecommunications regulator. In Tanzania, the Electronic and Postal Communication Act mandates equipment standardization and security

\footnotetext{
${ }^{181}$ SIM Registration in Africa: Subscribers Number Down But What About Revenue And ARPU?, TELECOMS, INTERNET \& BROAD. IN AFR. (May 13, 2011), available at: http://www.balancingact-africa.com/news/en/issue-no554/top-story/sim-registration-in/en.

${ }_{182}$ Masamila et al., supra note 181, at 179.

${ }^{183} \mathrm{Id}$. at 178 .

${ }^{184}$ Id.
} 
protocols. These standards are administered by the Tanzania Communications Regulatory Authority. ${ }^{185}$ Whereas in the Philippines, the financial regulator, Bangko Sentral ng Pilipinas (BSP), requires banks and non-banks engaged in issuing e-money to have "appropriate security policies and measures intended to safeguard the integrity, authenticity and confidentiality of data and operating processes" in place. ${ }^{186}$

Failure to comply with the minimum-security protocols permits the central bank from imposing sanctions on the offending institution. ${ }^{187}$ These examples serve to illustrate the methods employed to minimize systematic risk by industry regulators to combat security challenges within the mobile banking context. ${ }^{188}$

\section{H. Liability for Losses}

Liability allocation with respect to fraudulent use or impermissible transactions is critically important to microfinance institutions in regard to risk management. The underlying inquiry is based on whether the financial institution (MFI) or the telecommunications carrier bears the risk of loss of a failed mobile banking transaction. Unless the contractual partnership

\footnotetext{
${ }^{185}$ THE ELECTRONIC AND POSTAL COMMUNICATIONS ACT (2011), available at http://www.tcra.go.tz/regulation/draftRegulation/11_RegulationsElectronicCommunicationsEquipmentStandardsJun e2011.pdf. See also, Al-Amani Mutarubukwa, Government to Table Bill on Mobile Banking Regulations, THE CITIZEN (Feb. 23, 2011), available at http://www.thecitizen.co.tz/magazines/31-business-week/8517-govt-to-tablebill-on-mobile-banking-regulations.html ("We expect to have the regulations for the new law any time from now. What is awaited is an approval by the minister," said Tanzania Communications Regulatory Authority (TCRA) communications manager Innocent Mungy. "The regulations are intended to curb all the security matters brought by technological development such as mobile banking.").

${ }^{186}$ Bangko Sentral ng Pilipinas, Circular 649, § 4(H), (Feb. 26, 2009), available at http://www.bsp.gov.ph/downloads/Regulations/attachments/2009/c649.pdf (it is assumed that mobile banking is reflected in money transfer and issuance of e-money. This is to safeguard the mobile banking transactions).

${ }^{187}$ THE ElECTRONIC AND POSTAL COMMUNICATIONS REGULATIONS, supra note 186.

${ }^{188}$ E-Banking, Appendix E, FinANCIAL InSTITUTIONS EXAMINATION COUNCIL: IT EXAMINATION HANDBOOK, available at http://ithandbook.ffiec.gov/it-booklets/e-banking/appendix-e-wireless-banking.aspx (in the United States, security guidelines have been issued by the Federal Financial Institutions Examination Council (FFIEC), which advises financial institutions to employ a layered security approach).
} 
between the two entities specifies the allocation of liability, the answer is dependent on the regulatory structure of the jurisdiction. ${ }^{189}$

The issue has been addressed in recent 'phishing' cases. 'Phishing,' now more recently known as 'SMishing,' is a method used to illegally elicit consumer pin numbers and account numbers by sending text requests for information by fraudulently assuming to be a legitimate entity, such as a financial institution or specific department of the institution. ${ }^{190}$ Fraudsters typically send an email or text requesting the consumer to send their pin or account numbers, or they will call a specific telephone number, which then requires the consumer to enter his or her account number. ${ }^{191}$

Another method in defrauding consumers using mobile banking is by illegally obtaining duplicate SIM cards and using consumer information, or creating false consumer information for stolen SIM cards. ${ }^{192}$ In India, the central bank, the Reserve Bank of India (RBI), has imposed liability on banks for customer losses; now, this liability has been extended to mobile carriers. ${ }^{193}$ In Nashua Mobile (PTY) Ltd. vs. GC Pale CC t/a Invasive Plant Solution, the South African High Court deliberated over a 'phishing' case where the Plaintiff brought a negligence action

\footnotetext{
${ }^{189}$ See Electronic Fund Transfers, 12 C.F.R. $§ 205$ (2012) (governing mobile banking transactions in the United States).

${ }^{190}$ Mark Huffman, “Smishing” Emerging As New Threat To Cell Phone Users, Consumer AFFAIRS (Nov. 8, 2006), http://www.consumeraffairs.com/news04/2006/11/smishing.html; see also Android 'Smishing'Vulnerability Discovered by NCSU Researchers; Google Has a Fix Coming, ENGADGET (Nov. 2, 2012), http://www.engadget.com/2012/11/02/android-smishing-vulnerability-google-fix-patch-coming/.

${ }^{191}$ RonAld N. WeIKERS ET AL., DATA SECURITY AND PRIVACY LAW § 7:18 (West 2d ed. 2012).

${ }^{192}$ Indian Mobile Companies to share Phishing liability of Rs 3250 crores per annum?, BLOGGER NEWS (Sept. 22, 2011), http://www.bloggernews.net/127166 (see this blog generally for discussion of phishing cases).

${ }^{193}$ Id. Also, banks attempted to circumvent liability by blaming customers for responding to phishing emails, thereby constituting negligence. ICICI Bank told to pay Rs 13 lakh to NRI customer, THE ECONOMIC TIMES (Apr. 14, 2010), http://articles.economictimes.indiatimes.com/2010-04-14/news/28436533_1_internet-banking-icici-bankphishing. Further, India's Information Technology Act 2000 (amended 2008) has been used to impose liability on corporations (banks and telecom carriers) for negligence for failure to maintain security standards. Id (citing INFORMATION TECHNOLOGY ACT, 2000 §43(A), No. 21 OF 2000, INDIA CODE (2000), available at http://indiacode.nic.in/); see generally id. (discussing Umashankar Sivasubramaniam vs ICICI Bank, in which the adjudicator ordered "ICICI Bank to pay Rs 12.85 lakh to an Abu Dhabi-based NRI within 60 days for the loss suffered by him due to a phishing fraud.").
} 
against the mobile provider based on the mobile contractual relationship. ${ }^{194}$ The plaintiff contended that her SIM card was mistakenly duplicated by the defendant and used to fraudulently transfer money from her account. ${ }^{195}$

The plaintiff further argued that the "defendant should reasonably have foreseen the loss occurring because the details of the person to whom it negligently gave a SIM card did not match those contained in plaintiff's subscriber application form that formed part of the contract."196 The Court ultimately held that the defendant is not the proximate cause for the plaintiff's loss, as the mere duplication of a SIM card did not result in the fraudulent transfer.

The plaintiff failed to establish how the perpetrator could determine the plaintiff's PIN number and profile information as "no access can be gained to the plaintiff's account via the internet through SIM card alone."197 The Court further noted that it was unclear whether the plaintiff or her employees clicked on an e-mail link, or whether "the fraudster received a helping hand either inside the bank or inside the plaintiff from someone or people who had that information."198 This case can be distinguished from "SMishing" cases; in this instance, the mobile device was used to access the internet and use the plaintiff's banking information via the internet.

The risk of a typing error can also have unintended consequences during a mobile banking transaction. ${ }^{199}$ Typing errors may be quite common for people who may be numerically illiterate or are unable to navigate the small buttons on the handset. As such, MFI agents must be

\footnotetext{
${ }^{194}$ Nashua Mobile (PTY) Ltd. v. GC Pale t/a Invasive Plant Solutions, 2012 (1) SOUTH AFRICAN REPORTER [SA] 615 (GSJ) [South Gauteng High Court Johannesburg] (Oct. 18, 2010), available at http://www.saflii.org/za/cases/ZAGPJHC/2010/112.pdf.

${ }^{195} I d$. at para. 16, http://www.saflii.org/za/cases/ZAGPJHC/2010/112.pdf.

${ }^{196} \mathrm{Id}$.

${ }^{197} \mathrm{Id}$.

${ }^{198} \mathrm{Id}$

${ }^{199}$ Mark Budnitz, Mobile Financial Services: The Need for a Comprehensive Consumer Protection Law, 27 BANKING \& FIN L. REV. 213 (2012) (Can).
} 
cognizant of this particular issue during training and implementation. In ensuring a secure digital path, regulators see the value of investing more resources in bank security operations and employee training. ${ }^{200}$ The legal implications of mobile banking arise from various components embedded in national legal frameworks. For instance, MFIs may have to address the regulatory risks inherent in the operation with respect to participation or access to the payment system, security and privacy concerns. ${ }^{201}$ Hence, privacy enhancing practices and due diligence during transactions must be well established in order to ensure the integrity of value transfers.

\section{Deposit Insurance}

More recently, the question of whether deposit insurance protection should be a part of the microfinance regulatory scheme has been raised. As emerging economies start implementing deposit protection systems within their banking structure, the discussion on including microfinance institutions is ongoing. The issue whether funds held by MFIs are protected by deposit insurance schemes is simply dependent on the current regulation, the nature of the MFI, and capital requirements. ${ }^{202}$ In other words, the regulatory tension in this inquiry has continued to remain whether protection is afforded to actual transactions or services, or whether it is afforded to eligible financial institutions based on membership criteria.

In the Philippines, the regulator has deemed that electronic money is not considered a deposit, as the regulator has prohibited any payment of interest on e-money. ${ }^{203}$ Further, pursuant

\footnotetext{
${ }^{200}$ To illustrate, Bangladesh has sought research and investment advice from IT experts to enhance security within the banks. The Governor of Bank wants to establish a specific fund for research initiatives. See Atiur Seeks Help to Beef Up Banks’ IT Security, THE DAILY STAR, Oct. 16, 2011, available at http://www.thedailystar.net/newDesign/news-details.php?nid=206754.

${ }^{201}$ Mpakwana Annastacia Mthembu, Electronic Funds Transfer: Exploring the Difficulties of Security, 5 J. INT'L COMMERCIAL L. \& TECH. 201 (2010), available at http://www.jiclt.com/index.php/jiclt/article/download/115/113.

${ }^{202}$ For instance, MFIs can be classified as NGOs, banks - non-deposit taking institutions and deposit-taking microfinance institutions.

${ }^{203}$ Cent. Bank of Phil., E-Money CIRCUlar 649 (Mar. 2009).
} 
to the Circular, electronic money is not insured by the Philippines Deposit Insurance Corporation. $^{204}$ The Circular establishes redress mechanisms for consumer complaints, and imposes a requirement for tracking methods for electronic money instruments." 205

In the mobile banking context, funds transferred through mobile banking platforms operated by MFIs would have extended protection of deposit insurance if the actual MFI had met the eligibility criteria pronounced by the jurisdiction. To distinguish, M-PESA funds are held as deposits by Safaricom in commercial bank accounts. ${ }^{206}$ These deposits are insured by Kenya's Deposit Protection Fund, "however, this deposit insurance, designed for individual bank account holders, provides insurance on deposits up to a maximum of KSh 100,000 , or about $\$ 1,300$. Thus M-PESA deposits are virtually completely uninsured against bank failure."207 Arguably, Safaricom, as a bank account holder, may be eligible for protection under this scheme, but whether Safaricom will ensure (pass on the protection) that its customers' funds are protected rests on its business judgment, rather than any legal obligation. Conversely, "any interest earned cannot benefit Safaricom as it will trigger the business of banking."208

However, in certain cases, MFIs do not meet eligibility requirements as the capital holdings are still below the regulatory threshold to garner deposit insurance; as such, they are not protected by the national deposit insurance scheme. ${ }^{209}$ To resolve the eligibility discrepancies, Uganda developed two deposit insurance schemes to accommodate two distinctly different

\footnotetext{
${ }^{204} \mathrm{Id}$.

205 Notes on Regulation of Branchless Banking in the Philippines, CGPA (Jan. 2010), http://www.cgap.org/gm/document1.9.42402/Updated_Notes_On_Regulating_Branchless_Banking_Philippines.pdf.

${ }^{206}$ William Jack \& Tavneet Suri, Economics of M-PESA, Aug. 2010, available at http://www.mit.edu/ tavneet/MPESA.pdf

${ }^{207}$ Id. at 10

${ }^{208}$ Sultana, supra note 117 , at 10.

${ }^{209}$ JOANNE LEDGERWOOD \& VICTORIA WHITE, Transforming Microfinance Institutions: Providing Full Financial Services to the Poor, in A WORLD BANK PUBLICATION (2006) (many argue "that commercial banks may be reluctant to share their commonly funded deposit insurance schemes with newly licensed MFIs because they perceive these MFIs as high risks.").
} 
financial entities. Two deposit insurance funds were created for commercial banks and MFIs, which are governed by one board. ${ }^{210}$ In Uganda, the Microfinance Deposit-taking Institution Deposit Protection Fund (MDI-DPF) requires its members to contribute to the fund, and it also accepts donor funds to ensure that its customers' deposits are protected in the event of financial collapse. $^{211}$

MFIs are not immune to financial insolvency as bank failures have become an entrenched reality as a result of the global financial crisis. In the absence of deposit insurance schemes, MFI customers are left vulnerable and will be further driven into tenuous financial circumstances in the event of institutional insolvency. Compounding this issue is also the lack of regulatory and legislative consumer safeguards in this aspect, leaving customers without legal redress. The insolvency of mobile payment providers or their intermediaries, not attached to financial institutions, directly mirrors the problems encountered by customers, who suffer from bank failures in the absence of deposit insurance or consumer protection legislation. The advent of mobile banking has brought an onset of new legal issues, thereby requiring regulators to seek

\footnotetext{
${ }^{210}$ Ledgerwood further explains: "The problem that arises from such a scheme is that the contributions to the fund provided by the few regulated MFIs will not be sufficient to cover all the risks the fund should cover. It is also unclear how the operating expenses that normally should be covered out of the returns from investing the fund's unused capital in interest-bearing assets, can be funded. Either the government or a donor agency may need to provide the necessary seed capital for the establishment of an MFI deposit insurance fund large enough to operate on a cost-covering basis. However, it must be kept in mind that regulated MFIs are likely to mobilize relatively large amounts of deposits. Depending on the amount of coverage, the fund could easily be depleted if a single institution closes. In sum, the discussion on microfinance deposit protection schemes is fairly new and does not yet provide general experience to support ways to design such schemes." Id. at 45.

${ }^{211}$ A further $€ 2$ million is expected from the German Kreditanstalt fur Wiederaufbau (KfW) to boost the Fund. The amount from KfWwill be split between MDI-DPF Seed Capital ( $€ 1.8$ million) and the MDI-DPF Public Awareness Campaign ( $€ 0.2$ million). The Campaign will focus on making the public aware of the existence of the Fund and its benefits, which include guaranteed recovery of deposits in the event of MDI liquidation." Annual Supervision Report, BANK OF UGANDA (Dec. 2010), http://www.bou.or.ug/export/sites/default/bou/boudownloads/asr/2010/Dec/ASR_Dec_2010.pdf.
} 
new and creative solutions to address the challenges of technological advances while maintaining fiscal stability. ${ }^{212}$

\section{J. Proportional Regulatory Framework}

The current fragmented regulatory landscape demonstrates the uneven regulatory measures developed to address the legal issues within mobile banking. The preceding discussion highlights the regulatory tensions in balancing interests of regulators, industry and stakeholders. As illustrated, jurisdictions exercise various methods to augment telecommunication and financial regulation to accommodate mobile banking platforms. It is uncontroverted that mobile banking must be regulated, but the underlying issue continues to remain 'how and when' to impose regulatory requirements. $^{213}$

The axiomatic quandary is whether 'over' regulation may impinge on the expansion of mobile banking. Many jurisdictions recognize that regulation through taxation and licensing can be profitable. For instance, thirty percent (30\%) of sub-Saharan African tax revenue was derived from mobile-related taxation. ${ }^{214}$ As regulators attempt to reconcile competing interests, microfinance institutions are caught in the center of the regulatory discourse.

Regulators have differing positions in enacting legislation applicable to mobile banking; some jurisdictions have created legal obligations for specific institutions or activities, thereby challenging global partnerships and harmonizing efforts. The preferred method adopted is the 'test and see' approach used in Kenya and the Philippines, which permits mobile banking

\footnotetext{
212 Arnold S. Rosenberg , Better Than Cash? Global Proliferation of Payment and Consumer Protection Policy, 44 Colum. J. Transnat'L L. 520 (2006) (reprinted at 60 CONSUMER FIN. L. Q. ReP. 426 (2006)).

${ }^{213}$ Dias \& McKee, supra note 153.

${ }^{214}$ Mobile Services in Poor Countries: Not Just Talk, THE ECONOMIST (Jan. 27, 2011), http://www.economist.com/node/18008202.
} 
operations on an "ad hoc basis" or "follow the market." ${ }^{215}$ As the market develops, so does regulatory oversight. By not constraining innovation through legislation, regulators and industry stakeholders can mutually shape the legislative framework to adapt to new and emerging financial technologies. Regulators must engage in a balancing act by assessing whether uniform standards should be adopted, but it may not be the best approach if it stifles competition or innovation. ${ }^{216}$ "Mobile banking is set to become an instrument of differentiation." ${ }^{217}$ In order to render an efficient and stable regulatory environment, legislative harmonization and a system of mutual recognition to facilitate cross-border transactions is required. Regulatory ambiguity can be negated by adopting common measures to stimulate innovation, access and growth. The envisioned regulatory scheme, which oversees mobile banking, should be proportionate; legislation should be adapted to the current environment without being overly restrictive so as to impede technological innovation. ${ }^{218}$ Regulatory certainty for mobile banking stakeholders is a vital component in fiscal stability and economic development.

A mere liberalization of mobile banking practices and services, however, is insufficient, as a clear lack of adequate regulation is not a desirable approach. Liberalization of mobile banking fails to ensure the integrity and stability of the entire system, and may fail to provide sufficient consumer protection measures. For example, in Colombia, the lack of regulation has been cited for the failure of "expansion of financial services through new technologies because it creates legal uncertainty." ${ }^{219}$ Such uncertainty acts as a deterrent for financial institutions to

\footnotetext{
${ }^{215}$ Michael Tarazi, Branchless Banking: The Test and See approach, CGAP TeCHNOLOGY BLOG (Feb. 9, 2010), http://www.cgap.org/blog/branchless-banking-india-more-reasons-optimism.

${ }^{216}$ Dias \& McKee, supra note 153, at 1.

${ }^{217}$ Tiwari, Buse \& Herstatt, supra note 25, at 16.

${ }^{218}$ Lyman, Pickens \& Porteous, supra note 116, at 6 (citing the Committee on Payment and Settlement Systems and the World Bank 2007).

${ }^{219}$ Mauricio, Lozano, \& Mandrile, supra note 70, at 9.
} 
develop, invest and assume the risk of a mobile banking platform. Therefore, regulators have to adopt appropriate and proportionate legislation to combat these challenges.

\section{Part III: Consumer Perspective}

Telephones, mobile or landline, are facilitating devices that make possible effective action in many directions and functions as amplifiers of human agency. ${ }^{220}$

At the heart of the mobile banking narrative is the customer. The customer is the primary driver for innovation; her financial habits and the way she uses cellular technology are closely monitored by academics, industry insiders and the banking sector. Nokia, for example, uses "human-behavior researchers." These researchers are also referred to as "user anthropologists" who observe how individuals in various segments of communities use mobile phones. ${ }^{221}$ The researchers then transmit their findings back to Nokia. To illustrate further, one researcher observed how individuals in the Dharavi slum in Mumbai, India, safeguard their mobile phones during monsoon season. ${ }^{222}$ The phone is wrapped in plastic bags and hung on the wall to avoid any contact with water. The "on-the-ground intelligence gathering," which is deemed to be a central tenet of "human centered design," is employed by anthropologists, and the data is then poached by technological companies to develop fungible products. ${ }^{223}$

User-innovation literature clearly suggests that within the mobile banking context, " $85 \%$ of all the innovation resulted in South to North diffusion" of technology. ${ }^{224}$ This, in itself,

\footnotetext{
${ }^{220}$ Max Leonard Schaub, Lines Across the Desert: Mobile Phone Use and Mobility in the Context of Trans-Saharan Migration, SOCIAL SCIENCE RESEARCH NETWORK 3, Mar. 28, 2011, available at http://papers.ssrn.com/sol3/papers.cfm?abstract_id=1723623.

${ }^{221}$ Corbett, supra note 82.

${ }^{222}$ Id at 2.

${ }^{223}$ Id at 3 .

${ }^{224}$ Paul van der Boora, Pedro Oliveira \& Francisco Veloso, Innovation by Users in Emerging Economies: Evidence from Mobile Banking Services, SOCIAL SCIENCE RESEARCH NETWORK, Feb. 23, 2012, at 35-36, available at
} 
demonstrates how users in these geographic locations have adopted and shaped the use of mobile banking to address an unmet need of low financial access. The 'locus of innovation' has clearly been a factor in the expansion of mobile banking. ${ }^{225}$ The measurement of innovation is ostensibly determined by user need and experience.

\section{A. Consumer Trust}

The success in the uptake in mobile banking is grounded in consumer trust. ${ }^{226}$ Due to the 'invisible' nature of mobile banking, building consumer trust is essential for MFIs. The perceived uncertainty of relinquishing control over cash and sending it through electronic channels can cause consumer anxiety and reluctance. Therefore, initial consumer trust significantly affects the adoption of mobile banking and shapes mobile user behavior. ${ }^{227}$ Other aspects affecting consumer trust include the providers' branding power, marketing efforts, goodwill, reputation and corporate image. ${ }^{228}$ Furthermore, built-in structural assurance is also a determinant of consumer confidence in the use of mobile banking. The concept of 'structural assurance' can be described as an "institution-based trust mechanism," derived from "legal and technological structures," which ensure payment security and enforcement. ${ }^{229}$

MFIs challenged with manual recording or technical mistakes during mobile banking risk the loss of consumer trust. ${ }^{230}$ Examples of challenges include delays in messaging, inconsistent

http://papers.ssrn.com/sol3/papers.cfm?abstract_id=2009926\&http://papers.ssrn.com/sol3/papers.cfm?abstract_id=2 009926.

${ }^{225} I d$. at 8 .

${ }^{226}$ Tao Zhou, An empirical examination of initial trust in mobile banking, 21 INTERNET RESEARCH 527, 528 (2011), available at http://www.emeraldinsight.com/journals.htm?issn=1066-

$2243 \&$ volume $=21 \&$ issue $=5 \&$ articleid $=1955858 \&$ show $=$ html .

${ }^{227}$ Id. at 528.

${ }^{228} \mathrm{Id}$.

${ }^{229} I d$. at 530.

${ }^{230}$ Ventura et al., supra note 44, at 11. 
MFI records and poor customer service, which can lead to failed mobile banking operations in certain areas, as consumers opt out of mobile transactions. ${ }^{231}$

\section{B. Social Intermediation}

Social intermediation must be facilitated by MFIs in order to assist consumers in obtaining financial services and the adoption of mobile banking. Social intermediation is an interventionist strategy, which promotes the delivering ancillary services to complement the access to financial services. It is defined as "a process in which investments are made in the development of both human resources and institutional capital, with the aim of creating selfreliance of marginalized groups, preparing them to engage in formal financial intermediation."232 This process can also be employed as a risk mitigation mechanism, as it essentially prepares consumers prior to entering financial relationships with the financial entity.

Many microfinance recipients suffer from illiteracy and are not formerly educated. As such, they require financial literacy training and technical assistance prior to engaging in mobile banking. ${ }^{233}$ As mobile handsets become more technologically advanced, these consumers require one-on-one training in order to operate their mobile devices and comprehend its various functions. Language barriers may also impede the use of mobile banking, and some consumers may be unfamiliar with banking terms, such as "transaction," "account balance," and also may be unable to locate symbols. ${ }^{234}$ Therefore, human mediation is fundamental in ensuring the

\footnotetext{
${ }^{231} I d$.

${ }^{232}$ Hinson, supra note 91 , at 324 nn.51-52.

${ }^{233}$ Financial literacy is a large component within the microfinance context and it also plays a part in the uptake of mobile banking.

${ }^{234}$ Indrani Medhi, Aishwarya Ratanm and Kentaro Toyama, Mobile Banking Adoption and Usage by Low-Literate, Low-Income Users in the Developing World, INTERNATIONALIZATION, DESIGN \& GLOBAL DEV. 485, 492 (2009), available at http://research.microsoft.com/en-us/people/indranim/hcii2009_medhi_ratan_toyama.pdf.
} 
proper use of mobile banking. ${ }^{235}$ For instance, the agent retailer and mobile operators, or even a microfinance loan officer, may assist these consumers in using the mobile device. ${ }^{236}$

Illiterate consumers are served through voice recognition technology. ${ }^{237}$ The usage of the mobile phone may also create technological and numerical literacy, thereby empowering consumers in their capacity as active market participants or savvy entrepreneurs. The comfort and ease in which the consumer uses the device is an important aspect in developing a mobile banking platform. This process encompasses suitability, user experience, low learning curve, comfort, literacy, numeracy, and user interface components. ${ }^{238}$

The use of mobile banking has diversified the utility of the mobile device. Microfinance officers can use the device to collect, record, and store client information. ${ }^{239}$ The recordkeeping and tracing component may ameliorate corruption, which is otherwise rampant in cash based economies. $^{240}$ Through the convergence of banking and communication technology, a host of variable usages and outcomes are apparent, as discussed in this paper. In order for the seamless integration and adoption of mobile banking, consumer input is crucial and must be incorporated within consumer protection measures. Consumer protection is not necessarily axiomatic and posits a challenge for regulators.

\section{Redressal Mechanism}

Resolving consumer complaints as a result of failed mobile banking transactions have gradually become a part of the operational framework. MFIs have recently developed internal

${ }^{235}$ Id. at 492 (discussing how "human mediation was critical for successful transactions").

${ }^{236}$ Ivatury, supra note 2, at 154 (describing that the merchants are trained by the Uganda Microfinance Union to assist illiterate and poor consumers to use the mobile devices).

${ }^{237}$ Hinson, supra note 91, at 328. See also, Ivatury, supra note 2, at 151 n.12.

${ }^{238}$ Medhi, Ratanm \& Toyama, supra note 235, at 486.

${ }^{239}$ Nick Clayton, African Lessons in Mobile Commerce, WALL ST. J., Nov. 25, 2011, http://blogs.wsj.com/techeurope/2011/11/25/african-lessons-in-mobile-commerce/.

${ }^{240} I d$. 
dispute resolution mechanisms, such as appointing grievance officers or developing a layered grievance department, which encompass numerous regions. In India, Capshor Microcredit has implemented a Clients' Grievance Redressal Policy, which has created a structured dispute resolution system, ranging from telephone intake to branch and regional levels. ${ }^{241}$ Consumer protection measures have been promulgated by the Reserve Bank of India in order to ensure optimal financial inclusiveness. Pursuant to RBI directives, banks and MFIs using business correspondents must have a grievance apparatus in place and prominently display its existence and procedure. ${ }^{242}$ Certain jurisdictions, such as Brazil, Mexico and Colombia, have established advertising and disclosure requirements, whereby mobile banking providers must provide consumers with a toll-free customer service line, or publicly exhibit the channels of redress. ${ }^{243}$

Private forms of consumer empowerment have also emerged in India, such as Akosha, which is a web based consumer protection tool. ${ }^{244}$ Consumers can use the toll free number or email Akosha to resolve their complaints, for a fee, against a mobile company or financial institution. $^{245}$ Presumably, this online service can be used to assist disgruntled microfinance recipients with a failed mobile banking transaction; however, the fee, literacy and access to a landline or the internet are required, which clearly function as impediments to many consumers.

\footnotetext{
${ }^{241}$ Grievance Redressal Policy for Clients, CASHPOR MICRO CREDIT, http://www.cashpor.in/ClientGreivances.html (last visited July 27, 2012).

242 "The banks should constitute Grievance Redressal Machinery within the bank for redressing complaints about services rendered by the BCs and give wide publicity about it through electronic and print media. The name and contact number of the designated Grievance Redressal Officer of the bank should be made known and widely publicized. The designated officer should ensure that genuine grievances of customers are redressed promptly. The grievance redressal procedure of the bank and the time frame fixed for responding to the complaints should be placed on the bank's website. If a complainant does not get satisfactory response from the bank within 60 days from the date of his lodging the compliant, he will have the option to approach the Office of the Banking Ombudsman concerned for redressal of his grievance/s." RESERVE BANK OF INDIA, http://rbi.org.in/scripts/BS_ViewMasCirculardetails.aspx?id=6568 (last visited July 27, 2012).

${ }^{243}$ Dias \& McKee, supra note 153, at 10.

${ }^{244}$ AKOSHA, http://www.akosha.com (last visited Oct. 9, 2012).

245 Purba Das, Consumer complaints become a business, SuNDAY GUARDIAN (New Delhi), Nov. 13, 2011, http://www.sunday-guardian.com/business/consumer-complaints-become-a-business.
} 
Regulators have also employed indirect methods to foster consumer protection efforts with the microfinance sector. The Micro Finance Regulatory Council (MFRC) in South Africa is a private non-profit consumer protection entity appointed by the government to regulate the microfinance industry. ${ }^{246}$ Microfinance institutions that are registered with the MFRC enjoy the Usury Act exemption. ${ }^{247}$ Once these MFIs are registered, they are deemed to be regulated by the Council, which has investigative and prosecutorial power. These consumer redress initiatives exemplify the patchwork of dispute resolution strategies within the mobile banking context. Arguably, the ability to file and resolve complaints is a form of empowerment. The social dynamics and relationships as a result of mobile banking proliferation have also altered how microfinance institutions cater to their customers.

\section{Gender Empowerment through Digital Activism}

It is undisputed that the technology inequity between developed and developing countries, characterized as the 'digital divide,' is closely associated with the gender divide. ${ }^{248}$ Surprisingly, however, mobile banking has also prompted changes within households, thus changing the dimensions of gender roles. ${ }^{249}$ The mere possession of a cellphone with banking

\footnotetext{
${ }^{246}$ What is Microfinance?, MICROFINANCE FOCUS, http://www.microfinancefocus.com/what-microfinance (last visited Oct. 12, 2012) ("The Micro Finance Regulatory Council (MFRC) has been established in accordance with the Usury Act Exemption Notice of 1 June 1999. The MFRC, is a company incorporated under Section 21 of the Companies Act, and has been recognized as the official and single regulator of all money lending transactions falling within the scope of the Usury Act Exemption Notice.").

247 "Micro lenders who are not registered with the MFRC automatically fall under the scope of the Usury Act. The maximum interest that can be charged under the Usury Act is 20\% per year, for amounts under R 10000 and $17 \%$ per year for amounts above R 10000 . Borrowers who enter into loan contracts with unregistered lenders are advised that such contracts are in contravention of the Usury Act, if the interest rates charged are above the maximum limits." Exemption Notice, NAT'L CREDIT REGULATOR, http://www.ncr.org.za/the_act/Exemption\%20notice\%20definition.pdf (last visited Nov. 24, 2012).

${ }^{248}$ K. BALASUBRAMANIAN ET AL., USING MOBILE PHONES TO PROMOTE LIFELONG LEARNING AMONG RURAL WOMEN IN SOUTHERN INDIA, 31 DisTANCE EDUC. 193, 195 (2010).

${ }^{249}$ In some instances, when borrowing from moneylenders, women had to be accompanied by a male family member. See Apala LahiRi et Al., How Mobile Money CAN Drive FinanCial INClusion for Women at the
} 
capabilities affords a woman control over her finances, which can be construed as a step toward financial empowerment. ${ }^{250}$ "As with other domestic technologies it is expected that mobile money will at first re-affirm traditional patterns, but after a series of small changes, may in the end transform them."251 Not only does the user have 'control' over her own finances, but she enjoys the privilege of privacy in the use of her funds. The 'biography' of the user is changed by merely asserting financial control, using a personal technological device through time saving and other conveniences. ${ }^{252}$ Mobile banking has allowed women the ability to conduct business from any geographic location. As "institutional boundaries" become distorted, she has the "flexibility to exist in both domains," namely at home and at work. ${ }^{253}$ As a result of the domestication of mobile phones, gender dynamics have been altered within the household by fostering fiscal autonomy. Conversely, the mobile device is also perceived as a "cultural" objective or artifact, ${ }^{254}$ which can sustain traditional gender roles. The mobile device can become a tool of control or oppression through tracking and monitoring the user's financial footprints. These socio-cultural consequences in the microfinance context have been subject to academic

BOTTOM OF THE PYRAMID (BOP) IN INDIAN URBAN CENTERS, INTERNATIONALIZATION, DESIGN AND GLOBAL DEVElOPMENT 475-76 (Nuray Aykin ed., 2009).

${ }^{250}$ SUPRIYA Singh, MobILE REMITTANCES: DESIGN FOR FinANCIAL INCLUSION, INTERNATIONALIZATION, DeSIGN AND Global DEVElopMENT 515, 515 (Nuray Aykin ed., 2009).

${ }^{251} I d$. at 518 .

${ }^{252}$ BALASUBRAMANIAN ET AL., supra note 249, at 152.

${ }^{253} I d$. at 152.

${ }^{254}$ BALASUBRAMANIAN ET AL., supra note 249 (discussing the examination of use of mobile phones by teenage Palestinian girls, whose findings show that the mobile phone acquired meaning through ownership); Hiyam HijaziOmari \& Rivka Ribak, Playing with Fire: On the Domestication of the Mobile Phone among Palestinian Teenage Girls in Israel, UNIVERSITY OF HAIFA (Oct. 31, 2007), http://hevra.haifa.ac.il/com/faculty-panorama/AoIR-finaldraft-2007.pdf (reflecting on the notion of "domestication" as a framework for analyzing mobile communication media); see also, Silverstone, Hirsch \& Morley, The Moral ECONOMy of THE Household (Consuming Technologies: Media and Information in Domestic Spaces, 1992) (suggesting that the domestication technology framework can be applied to analyze technology and gender relationships). 
examination for some time, and more recently, interdisciplinary scholars are now studying the effects of mobile phones. $^{255}$

\section{E. Beyond Banking \& Technology}

The use of the mobile phone in emerging economies has expanded beyond financial services. Mobile phones are employed for various access needs: health related services, ensuring that pharmaceutical drugs are genuine, and not counterfeit, ${ }^{256}$ agricultural products and insurance, maternal health, ${ }^{257}$ and they act as a tool for learning another language, such as English. ${ }^{258}$ Additionally, scholars have established a nexus between mobile finance and mobile health deployment, and how various jurisdictions have expanded the usage of mobile phones. ${ }^{259}$ Mobile finance has provided patients with alternative payment methods, healthcare provider salary disbursement, and vehicles to purchase life insurance products. ${ }^{260}$ Insurance providers have consorted with microfinance institutions to deliver microinsurance products and funeral coverage to underserved communities. ${ }^{261}$ Consumers can purchase monthly insurance premiums and obtain insurance payouts through this delivery network.

\footnotetext{
${ }^{255}$ Hijazi-Omari \& Ribak, supra note 255.

256 MPEDIGREE, http://mpedigree.org/home/ (last visited Oct. 12, 2012) (Mpedigree is a nonprofit located in Ghana).

${ }^{257}$ MOBILE AlLIANCE FOR MATERnAL ACTION, http://www.mobilemamaalliance.org (last visited July 27, 2012) (USAID has partnered with Johnson and Johnson to bring awareness to expectant mothers by using mobile phones); also see United States Agency for International Development Press Release, Mobile Alliance for Maternal Action' Launched to Improve Maternal Health, PHILANTHROPY NEWS DiGEST, http://foundationcenter.org/pnd/news/story.jhtml?id=339200023 (last visited July 27, 2012).

${ }^{258}$ Mobile Services in Poor Countries: Not Just Talk, THE ECONOMIST (Jan. 27, 2011), http://www.economist.com/node/18008202. See also, BBC MEDIA ACTION JANALA, http://www.bbc.co.uk/mediaaction/where_we_work/asia/bangladesh/bbcjanala.html (last visited July 27, 2012).

${ }^{259}$ Menekse Gencer, Advancing the Dialogue on Mobile Finance and Mobile Health: Country Case Studies, MHEALTH ALLIANCE (Mar. 2012), http://www.technet21.org/index.php/documents/view-document/1429-advancingthe-dialogue-on-mobile-finance-and-mobile-health-country-case-studies-m.html (last visited July 27, 2012). ${ }^{260} \mathrm{Id}$.

${ }^{261}$ U.S. Agency for International Development, reviewed by Tara Chandani of Banyan Global, Microfinance and HIV/AIDS NOTE \#3 Microinsurance for Markets Affected by HIV/AIDSI, USDA REPORT (Apr. 2008), http://www.banyanglobal.com/pdf/Microfinance_and_HIVAIDS_NOTE_3_Microinsurance_for_Markets_Affected _by_HIVAIDS.pdf.
} 
New rapid technological advances employed by microfinance institutions have introduced various modes of obtaining services, such as the use of biometric and near field technology to access financial services. ${ }^{262}$ Biometrics is used to ascertain identity, which uses biological and physical attributes such as "fingerprints, various iris patterns, blood vessel patterns in the retina, voice inflections in speech, and hand shape/geometry." ${ }^{263}$ Near-FieldCommunications (NFC) is a contactless wireless technology, which currently enables the consumer to merely access services, or purchase digital or physical products without entering any personal account information, data or pin number.

Contactless microfinance payments or contactless banking is slowly gaining momentum in certain jurisdictions, as mobile handheld devices are now manufactured with the NFC chip built in. ${ }^{264}$ Presumably these innovative changes will affect the regulatory landscape within the microfinance context, and create a host of new questions. As technology often outpaces legislation, regulatory provisions should be wide enough to capture new products and services that may affect microfinance.

\section{PART IV: CONCLUSION}

This paper provides a current assessment of the numerous components that affect mobile banking deployment by microfinance institutions. It is not intended to provide specific policy

\footnotetext{
${ }^{262}$ The Christian Science Monitor on Biometrics \& Mobile Money at Opportunity Malawi, OPPORTUNITY INT’L (Apr. 15, 2011), http://www.opportunity.org/blog/the-christian-science-monitor-on-biometrics-mobile-money-atopportunity-malawi (using biometrics to access ATM of MFI). See also, Microfinance in Malawi, OPPORTUNITY INT'L, http://www.opportunity.org/our-work/where-we-work/microfinance-in-africa/microfinance-in-malawi (last visited July 27, 2012).

${ }^{263}$ Ravi Das, An Introduction to Biometrics: A Concise Overview of the Most Important Biometric Technologies, 17 KEESING J. OF DOCUMENTS \& IDENTITY 3, 3 (2006), available at http://www.biometricnews.net/publications/biometrics_article_introduction_to_biometrics.pdf.

${ }^{264}$ All Nokia Smartphones to be NFC-Enabled from 2011, AVGO-CYPRUS (July 19, 2010, 10:17 PM), http://avgo.org/blog/2010/07/19/AllNokiaSmartphonesToBeNFCenabledFrom2011.aspx (Nokia smartphones are manufactured with the NFC chip built in, thereby allowing consumers to participate in contactless commerce).
} 
interventions at this time, but provides a cohesive depiction of the current landscape. Further, this paper does not address the international aspect of mobile banking transactions within the microfinance context. The 'transnationalization' of mobile banking due to shrinking borders and international remittance transfers is a current phenomenon. As such, international mobile financial transactions have evoked regulatory inquiry from many directions. ${ }^{265}$

As brick-and-mortar banking branches become less relevant in the financial inclusion discussion, the expansion of mobile banking is becoming a more promising vehicle to offer financial services for microfinance consumers. Microfinance institutions, and their delivery mechanism, mobile banking, are used to bolster financial inclusion efforts. Regulators are also promulgating this policy agenda to the formal economy. In order to promote financial inclusion in India, the Reserve Bank of India (RBI), , granted authorization for 52 commercial banks to employ mobile banking, yet only 33 banks integrated mobile banking platforms as of December 2011. ${ }^{266}$ The RBI further removed the transaction limit on mobile banking, which was subject to a daily cap of $\$ 1000$ USD (RS 50,000). ${ }^{267}$ Banks can set their "own transaction limits based upon on their own risk perception and with approval of their respective boards. ${ }^{, 268}$

Whether financial inclusion is the optimal mode of ending fiscal inequality is beyond the scope of this paper, as a critical inquiry into this prevailing policy agenda may reveal a slew of problematic inquiries. However, the quest for financial inclusion does not only rest on bringing unbanked individuals into the financial system, but it also promotes financial integrity as it

\footnotetext{
${ }^{265}$ Benjamin Geva, The Wireless Wire: Do M-Payments and UNCITRAL Model Law on International Credit Transfers Match?, 27 BANKING \& FIN. L. REV. 249 (2012) (this paper provides an analysis of how low value international remittance transfers using mobile devices are treated by UNICITRAL Model Law on International Credit Transfers).

${ }^{266}$ R. Srividhya, RBI Miffed at Banks Not Pushing Mobile Banking, MYDigiTALFC.COM (Jan. 10, 2012), http://wrd.mydigitalfc.com/banking/rbi-miffed-banks-not-pushing-mobile-banking-805.

${ }^{267} I d$.

${ }^{268}$ RBI Removes Cap on Mobile Banking Transactions, MiCROFINANCE FoCUS (Dec. 24, 2011), http://www.microfinancefocus.com/rbi-removes-cap-mobile-banking-transactions.
} 
assists the regulator in monitoring "the movement and sources of money and supports law enforcement by diminishing the anonymity of informal transactions.",269

Within certain jurisdictions in Africa, bank accounts are no longer indicators of financial access or inclusion, as double the amount of people have mobile phones than bank accounts, which connects them to formal money system. ${ }^{270}$ The ease in which mobile banking entered the developing marketplace can be attributed to the fact that it filled a void, whereas in developed economies, mobile banking shares space with debit and credit cards. ${ }^{271}$ The integration of mobile banking into microfinance has become a necessity and a driver of economic growth and development.

Modern society has embraced technology as an enhancement mechanism. It is assumed that the technological advancements affecting daily lives inherently improve the quality of human life. As such, mobile banking has invariably become a huge sensation due to wireless innovation, thereby creating financial inclusion and improving the lives of many. Much of the scholarship to date has emphasized the prolific impact mobile banking has had on individuals, communities, and microfinance efforts. There is, however, a deficiency in research affecting consumer rights within the mobile banking context. ${ }^{272}$ The research at issue has failed to fully consider whether consumers of mobile banking understand their legal rights and obligations. ${ }^{273}$ Using the American context, it is still unclear which agency within the US financial system will

\footnotetext{
269 Bob Christen, Foreword to PIERRE-LAurent Chatain ET. Al., Protecting Mobile Money Against FinANCial CRimes: Global Policy Challenges and Solutions, at xi, xi (2011).

${ }^{270}$ Ignacio Mas, Capturing the Potential of M-Payments for the “Unbanked, ”E-FINANCE \& PAYMENTS L. \& POL'Y 7,7 (2011), available at http://papers.ssrn.com/sol3/papers.cfm?abstract_id=1858377.

${ }^{271}$ Bourreau \& Verdier, supra note 32.

${ }^{272}$ It is unclear why - maybe because mobile banking is still in its infancy.

${ }^{273}$ See generally, Mark Budnitz, Commentary: Technology As the Driver Of Payment System Rules: Will Consumers Be Provided Seatbelts and Air Bags?, 83 CHI.-KENT L. REV. 909 (2008) (discussing how "technology has greatly complicated payments law, hampering consumers' ability to understand their legal rights and obligations"). See also $i d$. at 910 n.7 (citing Gail Hillebrand, who states, "even all the disclosure and education in the world would not end some consumers' ignorance and confusion, for the applicability of the law is still unclear.").
} 
administer consumer protection claims during a failed mobile banking transaction. ${ }^{274}$

Furthermore, critics of the uniform standard setting lobby, argue that the imposition of uniform rules cannot be widely applied, as not all regulatory regimes or payment systems possess similar objectives. $^{275}$ However, consumer objectives appear to be similar because consumers expect authorized accurate transfers and redress mechanisms for failed transactions. ${ }^{276}$ In order for consumers to utilize low value transactions, "consumers need a minimum protection regardless of the amount of the payment." ${ }^{277}$ As such, MFIs should ensure that regulatory oversight within the jurisdiction extends to issues arising out of mobile banking transactions.

Despite the mass uptake of this catalytic invention, concerns over cultural and kinship shifts have emerged. As mobile banking facilitates faceless movement of money, personal contact between family members has decreased. The "disintegration of social relations" due to mobile banking has become an incipient focus for academics. ${ }^{278}$ This inquiry mirrors critiques within the technology discourse, which discusses the dichotomous effects that can distort and destroy human connection.

\footnotetext{
${ }^{274}$ BUDNITZ, supra note 200, at 224 (writing "the law is not clear about which government agencies are responsible for these facets as applied to mobile financial services. For example, because these services present many consumer protection issues, the Federal Reserve Board, FTC and the new Consumer Financial Protection Bureau may all be appropriate agencies to address these issues.").

${ }^{275}$ Budnitz, supra note 274, at 915.

${ }^{276} I d$.

${ }^{277}$ Id.

${ }^{278}$ Selay Marius Kouassi, Ivorian opinions divided on mobile banking, RADIO NETH. WORLDWIDE (Jan. 4, 2012), http://www.rnw.nl/africa/article/ivorian-opinions-divided-mobile-banking-0 (arguing that the introduction of money transfer through the mobile phone will lead to the disintegration of social relations). "When someone travels hundreds of kilometers to visit a relative in a village or in another city and give him/her money, the relative is happy not only to receive the money but also to see the person who sends the money. With the mobile banking services, the physical presence of the sender is no longer required. Yet, it is the physical presence of relatives that sets Africans apart." Id. See also Bill Maurer, Regulation as Retrospective Ethnography: Mobile Money and the Arts of Cash, 27 BANKING \& FINANCE L. REV. 299, 311 (2012), available at http://www.imtfi.uci.edu/files/imtfi/docs/2012/bankingfinance_law_review_27.2_maurer.pdf(finding “in Kenya, participants in savings and credit cooperatives missed the social interactions provided by their regular meetings when payment and withdrawal via M-PESA became possible").
} 
Finally, the meteoric rise in mobile banking has revealed the need to formulate a proportionate regulatory structure, which currently resembles a jigsaw puzzle, in that each component has a purpose to create a seamless network. Technological advances often outpace legislation within various legal disciplines, and courts and tribunals have been called upon to interpret and apply 'gap' fillers by using legal interpretation and policy mandates. ${ }^{279}$ The governance paradigm within mobile banking is a similar narrative, which requires a cohesive and standardized regulatory framework to enhance fiscal stability, especially within the microfinance context as it affects the most financially vulnerable. Despite the developments made by MFIs in deploying mobile banking platforms and delivering 'hope' electronically, the underlying problem remains that the 'puzzle' has not been completed due to the fragmented regulatory landscape, the velocity of technology and the reluctant interest of stakeholders designed to address these challenges as outlined in this paper.

\footnotetext{
${ }^{279}$ Vivek Wadhwa, Ethics in the age of acceleration, WASH. PosT, July 13, 2012, http://www.washingtonpost.com/national/on-innovations/ethics-in-the-age-ofacceleration/2012/07/13/gJQAzVDUiW_story.html.
} 